\title{
Modelling multi-phase halogen chemistry in the coastal marine boundary layer: investigation of the relative importance of local chemistry vs. long-range transport
}

\author{
D. Lowe ${ }^{1}$, J. Ryder ${ }^{1,2}$, R. Leigh ${ }^{3, *}$, J. R. Dorsey ${ }^{1}$, and G. McFiggans ${ }^{1}$ \\ ${ }^{1}$ Centre for Atmospheric Sciences, School of Earth, Atmospheric and Environmental Sciences, University of Manchester, \\ Manchester, M13 9PL, UK \\ ${ }^{2}$ Centre for Ecology and Hydrology, Midlothian, EH26 0QB, UK \\ ${ }^{3}$ Department of Physics and Astronomy, University of Leicester, Leicester, LE1 7RH, UK \\ *now at: Crichton Carbon Centre, Crichton University Campus, Dumfries, DG1 4ZL, UK
}

Received: 29 July 2010 - Published in Atmos. Chem. Phys. Discuss.: 18 August 2010

Revised: 12 January 2011 - Accepted: 27 January 2011 - Published: 2 February 2011

\begin{abstract}
Measurements of significant concentrations of IO, $\mathrm{I}_{2}$ and $\mathrm{BrO}$ in a semi-polluted coast environment at Roscoff, in North-West France, have been made as part of the Reactive Halogens in the Marine Boundary Layer (RHaMBLe) campaign undertaken in September 2006. We use a onedimensional column model, with idealised $\mathrm{I}_{2}$ emissions predicted using macroalgael maps and tidal data from the littoral area surrounding Roscoff, to investigate the probable causes for these observations. The coupled microphysical and chemical aerosol model simulates mixed-phase halogen chemistry using two separate particle modes, seasalt and non-seasalt, each comprising of eight size-sections. This work confirms the finding of a previous study that the $\mathrm{BrO}$ measurements are most likely caused by unknown, local sources. We find that the remote observations of $\mathrm{IO}$ and $\mathrm{I}_{2}$ are best replicated using the $\mathrm{I}_{2}$ recycling mechanism suggested by previous studies, but that such a mechanism is not wholly necessary. However in-situ measurements of $\mathrm{I}_{2}$ can only be explained by invoking an $\mathrm{I}_{2}$ recycling mechanism. We suggest that focussed observations of the changes in $\mathrm{NO}_{\mathrm{x}}$ and $\mathrm{NO}_{\mathrm{y}}$ concentrations, as well as changes in the nitrate fraction of the non-seasalt aerosol mode, in the presence of $\mathrm{I}_{2}$ bursts could be used to determine the atmospheric relevance of the predicted $\mathrm{I}_{2}$ recycling mechanism.
\end{abstract}

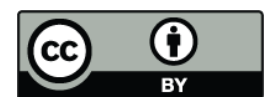

Correspondence to: G. McFiggans (g.mcfiggans@manchester.ac.uk)

\section{Introduction}

Research into tropospheric iodine and bromine radical species has been driven by their potential to influence important atmospheric chemical processes. These include changing the oxidative capacity of the atmosphere via destruction of ozone in catalytic cycles (Davis et al., 1996; Read et al., 2008), and by altering the partitioning of $\mathrm{NO}_{\mathrm{x}}$ and $\mathrm{HO}_{\mathrm{x}}(\mathrm{Mc}-$ Figgans et al., 2000; Platt and Hönninger, 2003; Bloss et al., 2005 ); and the formation and growth of new particles (Hoffmann et al., 2001; O'Dowd et al., 2002; McFiggans et al., 2004). Field measurements in the coastal marine boundary layer (MBL) have identified both bromine- and iodinecontaining inorganic species (e.g., Allan et al., 2000; SaizLopez and Plane, 2004; Saiz-Lopez et al., 2004; Peters et al., 2005). The main source of reactive bromine species in the MBL is likely to be sea-salt aerosol (Vogt et al., 1996; Sander et al., 2003). In addition the direct emission of organohalogens and molecular iodine by macroalgae will also contribute significantly to halogen loading in the coastal MBL (Carpenter et al., 1999; Palmer et al., 2005).

The Reactive Halogens in the Marine Boundary Layer (RHaMBLe) project at Roscoff, Brittany, was designed to investigate Marine Boundary Layer (MBL) chemistry in semipolluted conditions. To investigate daytime tidal signature of iodine photochemistry and new particle bursts. Roscoff was chosen for its large tidal range and extensive, well mapped, macroalgal beds; which indicated a good likelihood of significant $\mathrm{I}_{2}$ emissions. Measurements were conducted during September 2006. See McFiggans et al. (2010) for a detailed overview of the campaign. 
Remote measurements of $\mathrm{BrO}, \mathrm{IO}, \mathrm{OIO}, \mathrm{I}_{2}, \mathrm{NO}_{3}$, and $\mathrm{O}_{3}$ were made using a Long-Path Differential Optical Absorption Spectroscopy (LP-DOAS) instrument (Mahajan et al., 2009a,b). The light path of the LP-DOAS instrument extended out to the North-West, with an optical path length of $6.7 \mathrm{~km}$, crossing the inter-tidal zone at a height of 7-12 $\mathrm{m}$ above mean sea level. Measurements of iodine species showed a clear tidal relationship, high mixing ratios at low tide and vice versa. During the day the maximum mixing ratios measured for $\mathrm{I}_{2}$ and $\mathrm{IO}$ were $25.9 \pm 3.1 \mathrm{pmol} \mathrm{mol}^{-1}$ (measured on 19 September 2006) and $10.1 \pm 0.7 \mathrm{pmol} \mathrm{mol}^{-1}$ (9 September 2006), respectively (Mahajan et al., 2009b). No daytime measurements of OIO were above the LP-DOAS detection limit $\left(4 \mathrm{pmol} \mathrm{mol}^{-1}\right)$. $\mathrm{BrO}$ measurements did not exhibit a tidal relationship; the maximum mixing ratio measured by the LP-DOAS was $7.5 \pm 1.0 \mathrm{pmol} \mathrm{mol}^{-1}$ (Mahajan et al., 2009a).

In-situ measurements of IO were made with a Laser Induced Fluorescence (LIF) instrument (Whalley et al., 2007) and a open-path cavity ring-down spectroscopy (CRDS) instrument (Wada et al., 2007). During the campaign the maximum IO mixing ratio measured by the LIF instrument was $30 \pm 7 \mathrm{pmol} \mathrm{mol}^{-1}$. $\mathrm{I}_{2}$ was measured in-situ with the BroadBand Cavity RingDown Spectroscopy (BBCRDS) instrument (Leigh et al., 2010). In-situ $I_{2}$ mixing ratios were more variable than the IO mixing ratios, reaching a maximum of $50 \mathrm{pmol} \mathrm{mol}^{-1}$ (at low tide in the early evening of 14 September 2006), but only rising above the detection limit of the BBCRDS $\left(10-15 \mathrm{pmol} \mathrm{mol}^{-1}\right)$ on 4 out of the 10 days that measurements were taken. These differences in maximum mixing ratios between the remote and in-situ instruments support findings made during the North Atlantic Marine Boundary Layer EXperiment (NAMBLEX) (Heard et al., 2006) of spatial heterogeneity creating localised "hotspots" in which $\mathrm{I}_{2}$ mixing ratios were significantly greater than the path integrated values of the LP-DOAS instrument (Saiz-Lopez et al., 2006). $\sum\left(\mathrm{NO}_{3}+\mathrm{N}_{2} \mathrm{O}_{5}\right)$ was measured in-situ during the night using the BroadBand Cavity Enhanced Absorption Spectroscopy (BBCEAS) instrument (Langridge et al., 2008), reaching maximum mixing ratios of $80-90 \mathrm{pmol} \mathrm{mol}^{-1}$ during the early part of the campaign.

Three previous modelling studies have been conducted to examine iodine and bromine chemistry at Roscoff. Mahajan et al. (2009b) used a one-dimensional gas-phase photochemistry and transport model (THAMO) to investigate the LP-DOAS $\mathrm{I}_{2}$ and IO measurements. They calculated the ratios of the measured $\mathrm{I}_{2}: \mathrm{IO}$ concentrations, obtaining an average ratio of 3.8. Their modelled $\mathrm{I}_{2}: \mathrm{IO}$ ratio at the LP-DOAS measurement height $(\approx 10 \mathrm{~m})$ was too low without including a reaction for recycling $\mathrm{I}_{2}$ - for this they used the reaction:

$\mathrm{I}+\mathrm{IONO}_{2} \rightarrow \mathrm{I}_{2}$

with a rate of $5.5 \times 10^{-11} \mathrm{~cm}^{3}$ molecules ${ }^{-1} \mathrm{~s}^{-1}$ (Kaltsoyannis and Plane, 2008).
Leigh et al. (2010) used footprint concentration modelling to investigate the local macroalgal emission contributions to the remote and in-situ $\mathrm{I}_{2}$ measurements. Bathymetry and speciated macroalgal distribution information is mapped onto a two dimensional flat grid, Emission footprints were calculated for windspeed and tidal height, rotated due to wind direction, and then applied to the emissions grid to calculate concentration footprints. Chemistry was not included, however photolytic destruction of $\mathrm{I}_{2}$ was considered, and a simple recycling parameter was included, simulating the reforming of a certain proportion of the photo-dissociated $I_{2}$. It was found that reasonable correlations between modelled concentrations and data from the LP-DOAS and insitu BBCEAS instruments could only be obtained during the day through the implementation of a simulated recycling scheme such that $\mathrm{I}_{2}$ is maintained at the level it would have with approximately $95 \%$ slower photolysis, suggesting either unmodelled local emissions were involved, or a significant missing recycling or source component.

Mahajan et al. (2009a) used a gas-phase photochemical box model to investigate the conditions in which more than $5 \mathrm{pmol} \mathrm{mol}^{-1}$ of BrO can be generated in a mildly polluted environment. They found that the majority of bromine would be in the the form of $\mathrm{BrONO}_{2}\left(\approx 110 \mathrm{pmol} \mathrm{mol}^{-1}\right.$ for $>5 \mathrm{pmol} \mathrm{mol}^{-1} \mathrm{BrO}$ ). They examined a number of scenarios - eliminating sea-salt and biogenic bromine compounds as possible sources, instead suggesting that an unknown local source was the most likely cause.

The aim of this study is to investigate the importance of vertical transport and chemical mixing for the observations of concurrent high halogen oxide and $\mathrm{NO}_{2}$ levels at a semi-polluted coastal location. Towards this end a simple one-dimensional column model has been developed treating the evolution of the gas- and condensed-phase composition driven by vertical turbulent mixing and a highlydetailed representation of the multi-phase photochemistry. Although a reasonable multi-day simulation of the key processes has been used to ensure the model approaches the coastline with representative gaseous and condensed phase component loadings, the study focuses on detailed prediction of the coupled chemistry, microphysics and vertical transport that occurs as the emissions from the coastal zone mix into the background air. This then allows quantitative assessment of our understanding of the processes by comparison of the simulated behaviour with in situ measurements.

\section{Model description}

The one-dimensional column model used in this study is built around the box-model MANIC (Microphysical Aerosol Numerical model Incorporating Chemistry) (Lowe et al., 2009), which explicitly links aerosol chemistry and microphysics. A simple eddy diffusivity model is used to simulate vertical transport, driven by turbulence profiles generated off-line (no 
feedbacks between aerosols and heat fluxes are considered). Operator splitting is used, with microphysical and chemical processes being calculated in a separate step for each 1D column cell, followed by a vertical transport step for the whole column. Fluxes of gases and seasalt aerosol particles from the sea surface are considered, as well as entrainment of gases from the free troposphere - the important processes which are dealt with in the model are shown in Fig. 1.

\subsection{Microphysics and chemistry}

The chemistry scheme used is based on that of Pechtl et al. (2006), with the updates detailed in Lowe et al. (2009). Non-ideality of the major ions in the condensed phase $\left(\mathrm{H}^{+}\right.$$\left.\mathrm{Na}^{+}-\mathrm{NH}_{4}^{+}-\mathrm{HSO}_{4}^{-}-\mathrm{SO}_{4}^{2-}-\mathrm{NO}_{3}^{-}-\mathrm{Cl}^{-}\right)$is treated using PDFiTE (Partial Derivative Fitted Taylor Expansion, Topping et al., 2009). $\mathrm{I}_{\mathrm{x}} \mathrm{O}_{\mathrm{y}}$ chemistry has been included (Table 1, based on the schemes of Saiz-Lopez et al., 2008; Mahajan et al., 2009b) to simulate the conversion of reactive iodine to $\mathrm{I}_{2} \mathrm{O}_{3}, \mathrm{I}_{2} \mathrm{O}_{4}$, and (irreversibly) $\mathrm{I}_{2} \mathrm{O}_{5}$, which are viewed as likely candidates for new particle formation. Recent laboratory studies (Saunders et al., 2010) have shown that nucleation and growth of fine particles from gaseous iodine occurs without the involvement of $\mathrm{O}_{3}$ (and that these most likely form from the polymerisation of $\mathrm{I}_{2} \mathrm{O}_{3}$ and $\mathrm{I}_{2} \mathrm{O}_{4}$, without the formation of gaseous $\mathrm{I}_{2} \mathrm{O}_{5}$ ). This has led to the development of new chemistry models which do not use the $\mathrm{I}_{\mathrm{x}} \mathrm{O}_{\mathrm{y}}+\mathrm{O}_{3}$ reactions (Mahajan et al., 2010). The study of the formation and growth of ultrafine particles is, however, beyond the scope of this paper. Furthermore, the choice of particle formation route does not have a large influence on the rest of the gas-phase chemistry (not shown). So, for the purposes of this study, we will use the $\mathrm{I}_{\mathrm{x}} \mathrm{O}_{\mathrm{y}}+\mathrm{O}_{3}$ reactions to simulate the loss of reactive iodine to particle formation. Photolysis rates for most species are calculated from actinic fluxes, which were measured at Roscoff during the RHaMBLe campaign using a Metcon spectral radiometer (Edwards and Monks, 2003). We assume a quantum yield of 1.0 for the photolysis of OIO (Gómez Martín et al., 2009). The photolysis rates for $\mathrm{I}_{2} \mathrm{O}_{2}$, $\mathrm{I}_{2} \mathrm{O}_{3}$ and $\mathrm{I}_{2} \mathrm{O}_{4}$ are not based on the measured actinic fluxes, but are instead based on estimates made by Mahajan et al. (2009b).

Further simplification of the treatment of aerosol is provided by not considering coagulation or any possible phase separation, nor including organic aerosol components. The condensed-phase is split into two separate populations: seasalt and non-seasalt, each of which comprises 8 sizesections. This distinction is purely based on the aerosol origin - the same chemical reactions and microphysical processes are applied to each population during the model run. Aerosol dry deposition is treated using the resistance model of Slinn and Slinn (1980); wet deposition is not considered.

Seasalt aerosol particles are predominately generated by bubble bursting during whitecap formation caused by surface winds. Monahan et al. (1986) used observational and

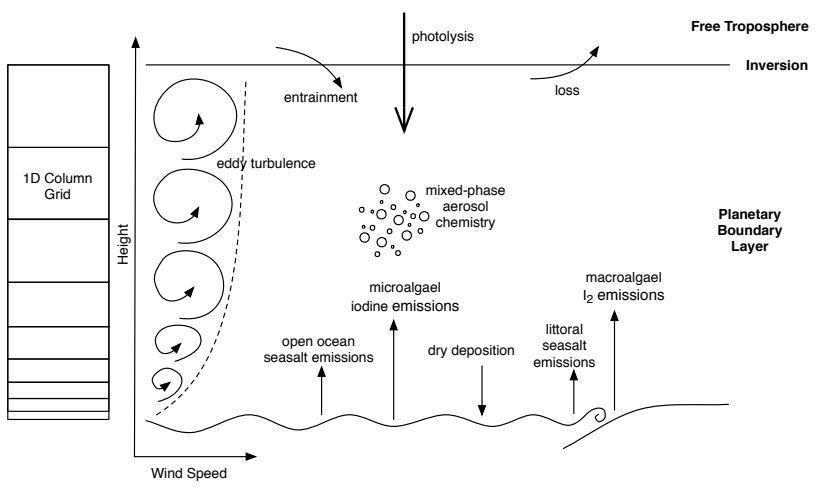

Fig. 1. Schematic of the major processes dealt with in MANIC-1D. An example, non-linear, vertical grid is shown on the left.

laboratory data of particle production for droplets between $0.4-20 \mu \mathrm{m}$ radii to parameterise this process. Their scheme, however, over-predicted production of seasalt particles with radii less than $0.2 \mu \mathrm{m}$ when compared with field measurements (O'Dowd et al., 1997). Gong (2003) introduced a new parameter, $\Theta$, to control the shape of the sub-micron size distributions, extending the applicability of the scheme down to dry radii of $0.02 \mu \mathrm{m}$. The particle number flux, $F_{\mathrm{N}}$, (in particles $\mathrm{m}^{-2} \mathrm{~s}^{-1}$ ) is given as

$\frac{d F_{\mathrm{N}}}{d r_{80}}=1.373 u_{10}^{3.41} r_{80}^{-A}\left(1+0.057 r^{3.45}\right) \times 10^{1.607 e^{-B^{2}}}$

where $A=4.7\left(1+\Theta r_{80}\right)^{-0.017 r_{80}^{-1.44}}, B=\frac{0.433-\log r_{80}}{0.433}, u_{10}$ is the wind speed (in $\mathrm{m} \mathrm{s}^{-1}$ ) at a height of $10 \mathrm{~m}$ above the ground, $r_{80}$ is the particle radius (in $\mathrm{m}$ ) at $\mathrm{RH}=80 \%$ and $\Theta=30$ (after Gong, 2003).

\subsection{1-D vertical transport scheme}

Vertical transport is determined by the diffusion equation:

$\frac{\delta c}{\delta t}=\frac{\delta}{\delta z}\left(K_{\mathrm{e}} \frac{\delta c}{\delta z}\right)+\frac{\delta\left(v_{\mathrm{T}} c\right)}{\delta z}$

where $c$ is concentration (either particles $\mathrm{cm}^{-3}$ or molecules $\left.\mathrm{cm}^{-3}\right), t$ is time (s), $z$ is height $(\mathrm{m}), K_{\mathrm{e}}$ is the eddy diffusivity $\left(\mathrm{m}^{2} \mathrm{~s}^{-1}\right)$, and $v_{\mathrm{T}}$ is the terminal settling velocity $\left(\mathrm{m} \mathrm{s}^{-1}\right)$. For gas-phase transport we assume that $v_{\mathrm{T}}=0$, while for particulate transport it is calculated using the scheme from Hoppel et al. (2005). Equation (2) is discretised following the formulation of ApSimon et al. (1994), enabling the use of a nonuniform grid. A fourth-order Runge-Kutta method is used to integrate the diffusion equation (Press et al., 1989), taking timesteps of $0.05 \mathrm{~s}$. $K_{\mathrm{e}}$ is prescribed in the model input files, the vertical profiles used for this case study are described below. 
Table 1. Additional $\mathrm{I}_{\mathrm{x}} \mathrm{O}_{\mathrm{y}}$ chemistry. $n$ is the order of the reaction. Reaction rates are given in $\left(\mathrm{cm}^{-3}\right)^{1-n} \mathrm{~s}^{-1}$

\begin{tabular}{llll}
\hline Reaction & $n$ & Rate & Reference \\
\hline $\mathrm{IO}+\mathrm{OIO} \longrightarrow \mathrm{I}_{2} \mathrm{O}_{3}$ & 2 & $1.5 \times 10^{-10}$ & Gómez Martín et al. (2007); Saiz-Lopez et al. (2008) \\
$\mathrm{OIO}+\mathrm{OIO} \longrightarrow \mathrm{I}_{2} \mathrm{O}_{4}$ & 2 & $1.0 \times 10^{-10}$ & Gómez Martín et al. (2007); Saiz-Lopez et al. (2008) \\
$\mathrm{I}_{2} \mathrm{O}_{2}+\mathrm{O}_{3} \longrightarrow \mathrm{I}_{2} \mathrm{O}_{3}+\mathrm{O}_{2}$ & 2 & $1.0 \times 10^{-12}$ & Saunders and Plane (2005); Saiz-Lopez et al. (2008) \\
$\mathrm{I}_{2} \mathrm{O}_{3}+\mathrm{O}_{3} \longrightarrow \mathrm{I}_{2} \mathrm{O}_{4}+\mathrm{O}_{2}$ & 2 & $1.0 \times 10^{-12}$ & Saunders and Plane (2005); Saiz-Lopez et al. (2008) \\
$\mathrm{I}_{2} \mathrm{O}_{4}+\mathrm{O}_{3} \longrightarrow \mathrm{I}_{2} \mathrm{O}_{5}+\mathrm{O}_{2}$ & 2 & $1.0 \times 10^{-12}$ & Saunders and Plane (2005); Saiz-Lopez et al. (2008) \\
$\mathrm{I}_{2} \mathrm{O}_{4} \longrightarrow 2 \mathrm{OIO}$ & 1 & $0.4($ at $290 \mathrm{~K})$ & Kaltsoyannis and Plane (2008) \\
$\mathrm{I}_{2} \mathrm{O}_{2} \longrightarrow \mathrm{OIO}+\mathrm{I}$ & 1 & $10.0($ at $290 \mathrm{~K})$ & Kaltsoyannis and Plane (2008) \\
$\mathrm{I}_{2} \mathrm{O}_{2} \longrightarrow \mathrm{IO}+\mathrm{IO}$ & 1 & $0.04($ at $290 \mathrm{~K})$ & Kaltsoyannis and Plane (2008) \\
$\mathrm{I}_{2} \mathrm{O}_{2}+h v \longrightarrow \mathrm{IO}+\mathrm{IO}$ & 1 & 0.06 (at midday) & estimated by Mahajan et al. (2009b) \\
$\mathrm{I}_{2} \mathrm{O}_{3}+h v \longrightarrow \mathrm{IO}+\mathrm{OIO}$ & 1 & 0.06 (at midday) & estimated by Mahajan et al. (2009b) \\
$\mathrm{I}_{2} \mathrm{O}_{4}+h v \longrightarrow \mathrm{OIO}+\mathrm{OIO}$ & 1 & 0.06 (at midday) & estimated by Mahajan et al. (2009b) \\
\hline
\end{tabular}

\section{Case study setup}

\subsection{1-D column layout and meteorology}

The 1-D column is set to $1000 \mathrm{~m}$ height, divided into $25 \mathrm{lev}$ els. The lowest $25 \mathrm{~m}$ of the column is split into 6 levels, with boundaries at $1,3,6,10$ and $15 \mathrm{~m}$.

Air pressure is assumed to decrease linearly with height (with a pressure of $1020 \mathrm{mbar}$ at the ground surface, and a lapse rate of $0.113 \mathrm{mbar}^{-1}$ ). The temperature profile follows a simple diurnal profile. During the day the ground surface temperature is $290 \mathrm{~K}$, decreasing at the dry adiabatic lapse rate $\left(9.76 \times 10^{-3} \mathrm{~K} \mathrm{~m}^{-1}\right)$ to the top of the column. At night the ground surface temperature is $284 \mathrm{~K}$, decreasing at the dry adiabatic lapse rate up to a height of $300 \mathrm{~m}$. Above this height air temperature increases again, to reach $282 \mathrm{~K}$ at the top of the column. Relative humidity is calculated on-line from pressure, temperature and the $\mathrm{H}_{2} \mathrm{O}$ mixing ratio.

A simplified eddy diffusivity profile is calculated off-line according to the parameterisation of Myrup and Ranzieri (1976), assuming that the atmospheric conditions are neutral:

$K_{\mathrm{e}}= \begin{cases}\kappa u_{*} z, & z / z_{i}<0.1 \\ \kappa u_{*} z\left(1.1-z / z_{i}\right), & 0.1 \leq z / z_{i} \leq 1.1 \\ 0, & z / z_{i}>1.1\end{cases}$

where $z$ is height of column-section edge (in $\mathrm{m}$ ), $z_{i}$ is the characteristic vertical length-scale (in $\mathrm{m}$ ) (in this instance the mixed-layer depth), $\kappa$ is the dimensionless von Karman constant. $u_{*}$ is the friction velocity (in $\mathrm{m} \mathrm{s}^{-1}$ ), calculated using the ACASA (Advanced-Canopy-Atmosphere-Soil Algorithm) model (described in Pyles et al., 2003, 2004) for the lowest $70 \mathrm{~m}$ of the model column. Above $70 \mathrm{~m}$ we assume that $u_{*}$ is constant (equal to the value at $70 \mathrm{~m}$ ). $z_{i}$ is set to $300 \mathrm{~m}$ during the night, and is set to $900 \mathrm{~m}$ during the day. Dawn is at 06:30 LT (Local Time), dusk at 17:30 LT, and the transition from day to night conditions is linear over the hour following dawn and dusk.
Photolysis rates are calculated from solar irradiance measured on the day of 23 September 2006 under close to clear sky conditions.

Included in the Supplement are the column section heights; pressure, temperature and eddy diffusivity vertical profiles; and a plot of the solar irradiance.

\subsection{Trajectory configuration}

The model is given a $59 \mathrm{~h}$ spin-up period before the final hour approaching the coastline, to allow the model chemistry to adopt more realistic and stable component loadings on the approach to the coastline (in comparison to the rather simplistic initial conditions). One particular background scenario has been chosen to provide the most frequently observed polluted marine conditions encountered during the RHaMBLe field project. This entails running a background marine airmass across the UK and then the Channel before finally arriving at Roscoff (an example trajectory of this type is included in the Supplement).

The first $48 \mathrm{~h}$ of the model run (starting at midnight) are across a clean marine environment, representative of conditions above the Atlantic. The gas-phases of all levels in the vertical column are initialised with the mixing ratios given in Table 2 (fixed species are constant at the given mixing ratios throughout the whole vertical column and model run). The model is initialised with two aerosol modes - one seasalt, the other non-seasalt - with initial distributions which are also consistent throughout the whole column. The seasalt initial distribution is a pseudo-lognormal, bi-modal, distribution (Porter and Clarke, 1997), which is linearly scaled to yield a dry mass of $15 \mu \mathrm{g} \mathrm{m}_{\text {air }}^{-3}$ (after Toyota et al., 2001). The dry mass fractions used are $0.994317 \mathrm{NaCl}, 0.001491498$ $\mathrm{NaBr}, 1.372178 \times 10^{-7} \mathrm{NaI}, 4.812565 \times 10^{-7} \mathrm{NaIO}_{3}$, and $0.004176193 \mathrm{NaHCO}_{3}$. The non-seasalt initial distribution is given in Table 5. The initial dry mass fractions of the 
Table 2. Initial gas-phase chemical mixing ratios (given in pmol mol${ }^{-1}$ ).

\begin{tabular}{lrl}
\hline Species & Mixing Ratio & Reference \\
\hline $\mathrm{NO}_{2}$ & 20 & after von Glasow et al. (2002) \\
$\mathrm{HCHO}$ & 300 & after von Glasow et al. (2002) \\
PAN & 10 & after von Glasow et al. (2002) \\
$\mathrm{CO}$ & 70000 & after von Glasow et al. (2002) \\
$\mathrm{HNO}_{3}$ & 10 & estimated \\
$\mathrm{SO}_{2}$ & 90 & after von Glasow et al. (2002) \\
$\mathrm{DMS}$ & 60 & after von Glasow et al. (2002) \\
$\mathrm{H}_{2} \mathrm{O}_{2}$ & 600 & after von Glasow et al. (2002) \\
$\mathrm{C}_{2} \mathrm{H}_{6}$ & 500 & after von Glasow et al. (2002) \\
$\mathrm{HCl} \mathrm{H}_{3} \mathrm{I}$ & 40 & estimated \\
$\mathrm{C}_{3} \mathrm{H}_{7} \mathrm{I}$ & 2 & after von Glasow et al. (2002) \\
$\mathrm{NH}_{3}$ & 1 & after von Glasow et al. (2002) \\
$\mathrm{O}_{3}$ & 80 & estimated \\
\hline
\end{tabular}

non-seasalt mode are $0.46 \mathrm{NH}_{4} \mathrm{NO}_{3}, 0.18 \mathrm{NH}_{4} \mathrm{HSO}_{4}$ and $0.36\left(\mathrm{NH}_{4}\right)_{2} \mathrm{SO}_{4}$.

During this ocean leg seasalt aerosol is emitted using Eq. (1) and a wind speed of $5.25 \mathrm{~m} \mathrm{~s}^{-1}$. The composition of this fresh aerosol is the same as that for the initial seasalt distribution, given above. Gas emissions from the ocean surface are given in Table 3, and the gas deposition rates used throughout the whole model run are given in Table 4.

Following the Atlantic leg the column is run across a polluted land environment for $6 \mathrm{~h}$, representing passage over the UK. Seasalt emissions are switched off, and the landbased emissions given in Table 3 are used. These source terms were chosen to ensure the modelled $\mathrm{NO}_{\mathrm{x}}$ concentrations were within the range of $\mathrm{NO}_{\mathrm{x}}$ concentrations measured at Roscoff during the RHaMBLe campaign.

A $5 \mathrm{~h}$ run across a marine environment is made again, simulating the air column crossing the English Channel. Seasalt aerosol and gas-phase emissions are the same as for the Atlantic leg. A snapshot of the gas- and condensed-phase mixing ratios throughout the entire column is taken at the end of the Channel leg. This is used to initialise the $1 \mathrm{~h}$ Roscoff runs which are discussed in this paper.

Plots of prognostic variables for the spin-up period have been included in the Supplement.

\subsection{Roscoff leg settings}

The model study presented in this paper consists of the last hour of the run, leading into Roscoff. Two scenarios are considered: high-tide, in which the model runs over the sea for the whole hour (as for the Channel leg); and low-tide, which is part sea and part intertidal exposed shoreline. The exposed intertidal section has no aerosol or gas emissions (unlike the sea or UK sections) other than localised $\mathrm{I}_{2}$ emissions from
Table 3. Gas-phase source terms, in molecules $\mathrm{cm}^{-2}$. The Sea terms are used for the Atlantic and Channel legs of the model run (and for the sea-section of the Roscoff leg). The Land terms are used for the UK leg of the model run - the $\mathrm{NO}_{\mathrm{x}}$ term is split between $\mathrm{NO}$ and $\mathrm{NO}_{2}$ based on the NO: $\mathrm{NO}_{2}$ of the lowest level of the model column at that point in time.

\begin{tabular}{|c|c|c|}
\hline Species & Source Term & Reference \\
\hline \multicolumn{3}{|l|}{ Sea } \\
\hline NO & $2 \times 10^{8}$ & estimated \\
\hline $\mathrm{NH}_{3}$ & $4 \times 10^{8}$ & estimated \\
\hline DMS & $2 \times 10^{9}$ & Quinn et al. (1990); Sander and Crutzen (1996) \\
\hline $\mathrm{CH}_{3} \mathrm{I}$ & $6 \times 10^{6}$ & Vogt et al. (1999) \\
\hline $\mathrm{C}_{3} \mathrm{H}_{7} \mathrm{I}$ & $1 \times 10^{7}$ & Vogt et al. (1999) \\
\hline $\mathrm{CH}_{2} \mathrm{ClI}$ & $2 \times 10^{7}$ & Vogt et al. (1999) \\
\hline $\mathrm{CH}_{2} \mathrm{I}_{2}$ & $3 \times 10^{7}$ & Vogt et al. (1999) \\
\hline $\mathrm{CH}_{2} \mathrm{BrI}$ & $2 \times 10^{7}$ & Vogt et al. (1999) \\
\hline \multicolumn{3}{|l|}{ Land } \\
\hline $\mathrm{NO}_{\mathrm{x}}$ & $5 \times 10^{11}$ & estimated \\
\hline $\mathrm{NH}_{3}$ & $1 \times 10^{11}$ & estimated \\
\hline $\mathrm{SO}_{2}$ & $1 \times 10^{11}$ & estimated \\
\hline $\mathrm{CO}$ & $2 \times 10^{12}$ & estimated \\
\hline
\end{tabular}

macroalgae generated by a footprint emissions model for the measurement site at Roscoff (Leigh et al., 2010). This combines tidal data, macroalgael maps, and wind speed and direction data taken at the in-situ measurement site during the RHaMBLe campaign.

The Leigh et al. (2010) model has been adapted for this study. For each 1-min model timestep, the emission footprint applied was reduced to the width of a single model cell $(55 \mathrm{~m})$, and extended upwind from the measurement site to the calculated sea edge. $I_{2}$ emissions within this footprint were characterised by transport time to site, assuming a constant wind speed and direction along the trajectory. $I_{2}$ emissions were calculated for every $30 \mathrm{~s}$ section of the trajectory.

For this study we have used two emission scenarios. The first is the back trajectory with the highest calculated total $\mathrm{I}_{2}$ emission from the whole campaign, which we will use for comparing with the LP-DOAS measurements. This occurred on the 10 September 2006, arriving at Roscoff at 12:33 p.m. For the purposes of this study, however, we assume that this airmass arrives into our model "Roscoff" at 12:00 LT (blue line, Fig. 2). There are three $\mathrm{I}_{2}$ bursts. The first is from 11.7375 to $11.7875 \mathrm{~h}$ (lasting $3 \mathrm{~min}$ ), with a peak emission rate of $8.26 \times 10^{9}$ molecules $\mathrm{cm}^{-2} \mathrm{~s}^{-1}$. The second and third bursts are shorter, 1 and $1.25 \mathrm{~min}$ long, respectively, and starting at 11.9292 and $11.9792 \mathrm{~h}$. The peak emission rates are also much lower, $1.04 \times 10^{9}$ and $1.95 \times 10^{7}$ molecules $\mathrm{cm}^{-2} \mathrm{~s}^{-1}$, respectively.

The second emission scenario has been chosen because it has higher $I_{2}$ emissions closer to Roscoff than the first scenario. It will be used, along with the first scenario, for comparison with in-situ measurements. This emission 
Table 4. Gas-phase loss velocities, $v_{\mathrm{d}, \mathrm{g}}$, in $\mathrm{cm} \mathrm{s}^{-1}$. Representing deposition at base of model column (estimated, consistent with estimations used in other models).

\begin{tabular}{ll}
\hline Species & $v_{\text {d,g }}$ \\
\hline $\mathrm{O}_{3}$ & 0.04 \\
$\mathrm{H}_{2} \mathrm{O}_{2}$ & 0.5 \\
$\mathrm{NO}_{2}$ & 0.1 \\
$\mathrm{~N}_{2} \mathrm{O}_{5}$ & 1.0 \\
$\mathrm{HNO}_{3}$ & 2.0 \\
$\mathrm{NH}_{3}$ & 0.1 \\
$\mathrm{HCHO}$ & 0.5 \\
$\mathrm{HCOOH}$ & 1.0 \\
$\mathrm{HCl}$ & 2.0 \\
$\mathrm{HOCl}$ & 1.0 \\
$\mathrm{ClNO}_{3}$ & 1.0 \\
$\mathrm{HBr}$ & 2.0 \\
$\mathrm{HOBr}$ & 1.0 \\
$\mathrm{BrNO}_{3}$ & 1.0 \\
$\mathrm{CH}_{3} \mathrm{SOCH}$ & 1.0 \\
$\mathrm{SO}_{2}$ & 0.5 \\
$\mathrm{H}_{2} \mathrm{SO}_{4}$ & 1.0 \\
$\mathrm{CH}_{3} \mathrm{SO}_{3} \mathrm{H}$ & 1.0 \\
$\mathrm{HI}$ & 1.0 \\
$\mathrm{HOI}^{\mathrm{INO}_{3}}$ & 1.0 \\
$\mathrm{INO}_{2}$ & 1.0 \\
\hline & 1.0 \\
\hline
\end{tabular}

scenario is also from the 10 September 2006, arriving at Roscoff at 13:48 p.m. (again we assume that this airmass arrives at our model "Roscoff" at 12:00 LT; red line, Fig. 2). Again, there are three $I_{2}$ bursts. The first is from 11.8625 to $11.8792 \mathrm{~h}$ (lasting $1 \mathrm{~min}$ ), with a peak emission rate of $6.67 \times 10^{9}$ molecules $\mathrm{cm}^{-2} \mathrm{~s}^{-1}$. The second burst is shorter, $0.5 \mathrm{~min}$ long, starting at $11.8958 \mathrm{~h}$, with a much lower peak emission rate of $9.07 \times 10^{7}$ molecules $\mathrm{cm}^{-2} \mathrm{~s}^{-1}$. The third burst is the longest, $3 \mathrm{~min}$ long, starting at $11.9292 \mathrm{~h}$. The peak emission rate is $3.342 \times 10^{9}$ molecules $\mathrm{cm}^{-2} \mathrm{~s}^{-1}$.

\section{Results and discussion}

Here, the gas- and condensed-phase chemical behaviour in the last hour of the model run approaching Roscoff is examined in detail. The model reaches Roscoff at midday (12:00 LT). The major gas- and condensed-phase species for the base case, low tide, model run are plotted below (Figs. 3, 5, 6, 7 and 8). Data from the other runs will be included where relevant to the discussion, however plots of major chemical species data from all model runs are also included in the Supplement.
Table 5. Parameters for the non-seasalt aerosol distribution used in study. The total number density, $N_{\text {tot }}$, is given in $\mathrm{cm}^{-3}$. The median radius for the log-normal number distribution, $R_{N}$, is given in $\mu \mathrm{m}$. The log-normal distribution width, $\sigma$, is dimensionless. The lognormal particle number size distribution is calculated according to $\frac{d N(r)}{d \ln r}=\frac{N_{\text {tot }}}{\ln \sigma \sqrt{2 \pi}} \times \exp \left(-\frac{\left(\ln r-\ln R_{N}\right)^{2}}{2(\ln \sigma)^{2}}\right)$, where $N(r)$ is the number density for particle radius $r$.

\begin{tabular}{lccc}
\hline Mode & $N_{\text {tot }}$ & $R_{\mathrm{N}}$ & $\sigma$ \\
\hline non-seasalt & 300 & 0.088 & 1.29 \\
\hline
\end{tabular}

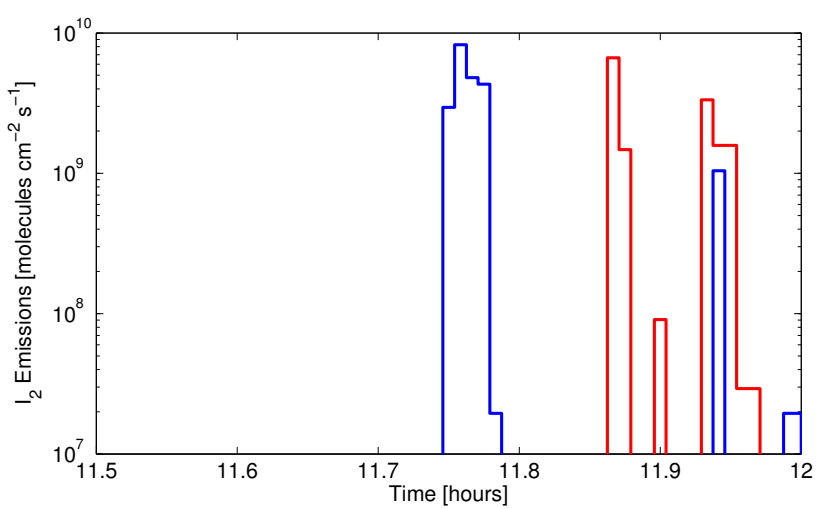

Fig. 2. Two $I_{2}$ emission scenarios used for the "low tide" model runs. The blue and red lines are for scenarios calculated using back trajectories from the Roscoff measurement site at 12:33 and 13:48, respectively, on 10 September 2006 (using an adapted version of the model of Leigh et al., 2010, see main text for details).

\subsection{Low tide base case}

At the start of the Roscoff leg the air column is still over the sea. Strong vertical gradients in the mixing ratios of gasphase halogen species and pollutants, such as $\mathrm{HNO}_{3}$ (Fig. 3) are observed. These result from the source of fresh seasalt, which maintains higher seasalt aerosol volumes in the lowest $10-20 \mathrm{~m}$ of the column (Fig. 4). The largest seasalt particles experience rapid turnover at the base of the column, producing a strong gradient in composition across vertical- and size-space for seasalt particles (Figs. 5 and 6). The $\mathrm{pH}$ of the largest, and vertically lowest, seasalt particles is around 910 , as compared to a $\mathrm{pH}$ of 5-4 for the smallest, and highest vertically, particles. Likewise the $\mathrm{Br}^{-}$content of the largest particles at the base of the column is close to that of fresh seasalt, while at a height of $650 \mathrm{~m}$ the mole fraction of $\mathrm{Br}^{-}$ in the smallest particles has been reduced by a factor of 100 . $\mathrm{Cl}^{-}$remains relatively undepleted in the largest seasalt particles (the molar ratio of $\mathrm{Cl}^{-}$to $\mathrm{Na}^{+}$is $\leq 0.8$ for the three largest size bins, indicating a loss of less than $20 \%$ of the initial $\mathrm{Cl}^{-}$content of these particles). The $\mathrm{Cl}^{-}$content of the smaller seasalt particles is more depleted, and the pollutant 

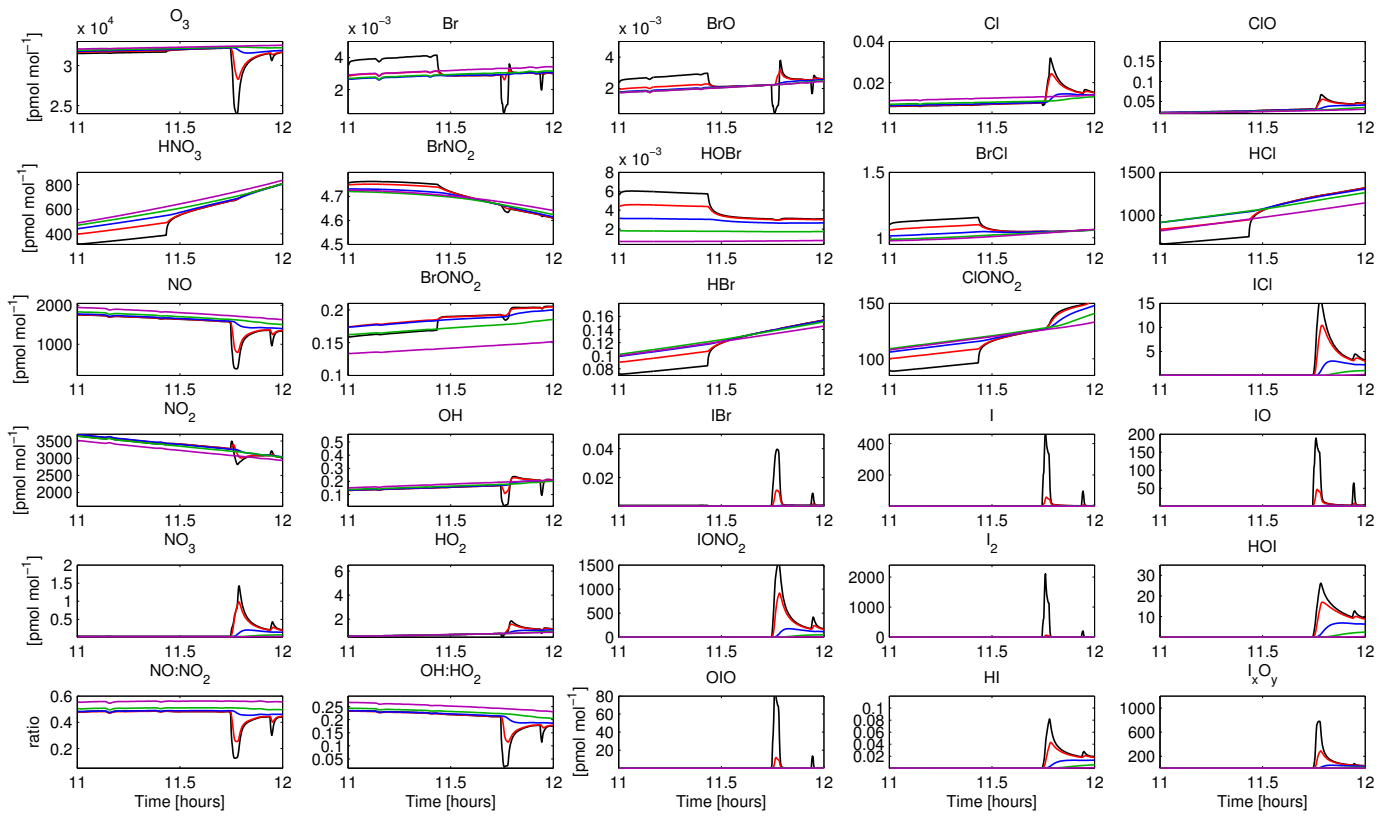

Fig. 3. Mixing ratios of major gas-phase chemical species at different levels through the model column for the base case, low tide, model run. Black, red, blue, green, and purple lines represent mixing ratios at heights of $0.5,8,60,250$ and $650 \mathrm{~m}$.
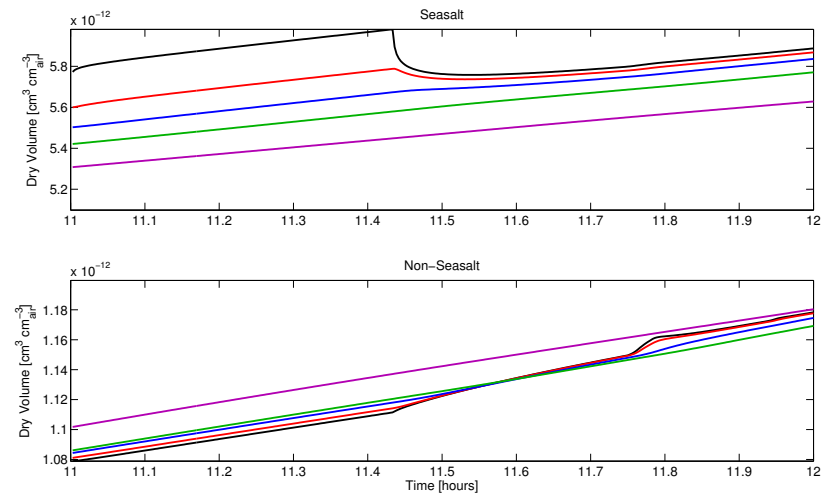

Fig. 4. Total dry volume for the seasalt and non-seasalt modes at different levels through the model column for the base case, low tide, model run. Black, red, blue, green, and purple lines represent mixing ratios at heights of $0.5,8,60,250$ and $650 \mathrm{~m}$.

( $\mathrm{NO}_{3}^{-}$and sulphate) content of these particles is much higher, due to their higher surface area to volume ratio (and so higher gas-aerosol transfer rate compared with total mass). The non-seasalt mode exhibits marked vertical-dependence, but little or no size-dependence, in composition (Figs. 7 and 8). $\mathrm{pH}$ decreases with height, as the relative humidity decreases. The $\mathrm{HSO}_{4}^{-}: \mathrm{SO}_{4}^{2-}$ ratio changes with $\mathrm{pH}$. $\mathrm{NO}_{3}^{-}$and $\mathrm{Cl}^{-}$content increases with height. $\mathrm{Br}^{-}$and $\mathrm{I}^{-}$content is minor at all heights.
At $11: 43 \mathrm{~h}$ the air column crosses from the sea to the beach. This stops the injection of fresh seasalt into the model column, halting this source of halogens, and leading to a reduction in seasalt aerosol volume and surface area (Fig. 4) due to sedimentation. The effects of stopping this seasalt source term can been seen almost immediately in the gasphase (Fig. 3). The mixing ratios of halogen species in the lowest few sections relax back towards the mixing ratios observed higher in the model column; as do the mixing ratios of $\mathrm{HNO}_{3}$ and $\mathrm{O}_{3}$. The increase in $\mathrm{HNO}_{3}$ mixing ratio is the result of the decrease in seasalt aerosol mass, and the rapid acidification of the largest seasalt particles (Fig. 5), in the lowest sections of the column; diffusive mixing then reduces the vertical gradient in mixing ratio. Chlorine and bromine species reactions to the switching off the seasalt source term are mixed. The mixing ratios of $\mathrm{Br}, \mathrm{BrCl}, \mathrm{BrO}$, and $\mathrm{HOBr}$ drop, mostly due to vertical mixing bringing these species closer to the mixing ratios of the main body of the column. Conversely, the mixing ratios of $\mathrm{BrONO}_{2}, \mathrm{HBr}, \mathrm{ClONO}_{2}$, $\mathrm{HCl}$, and $\mathrm{ClO}$ increase. This is likely to be due to a reduction in aerosol processing (due to loss of $\mathrm{Cl}^{-}$and $\mathrm{Br}^{-}$, and reduction in surface area) for the halogen nitrates, while the increases in the chlorine species will also be due to the release of chlorine from the largest seasalt particles as they become much more acidified (the drop in $\mathrm{pH}$ is matched by a reduction in the $\mathrm{Cl}^{-}: \mathrm{Na}^{+}$ratio from $\approx 0.95$ to $\approx 0.8$ ).

At 11:74, 11:93 and 11:98 $\mathrm{h}$ there are $\mathrm{I}_{2}$ bursts, simulating iodine emissions by macroalgae (Fig. 2). In the lowest level $(0-1 \mathrm{~m})$ the $\mathrm{I}_{2}$ mixing ratios reach a maximum of $2100 \mathrm{pmol} \mathrm{mol}^{-1}$ during the first burst (Fig. 9). 

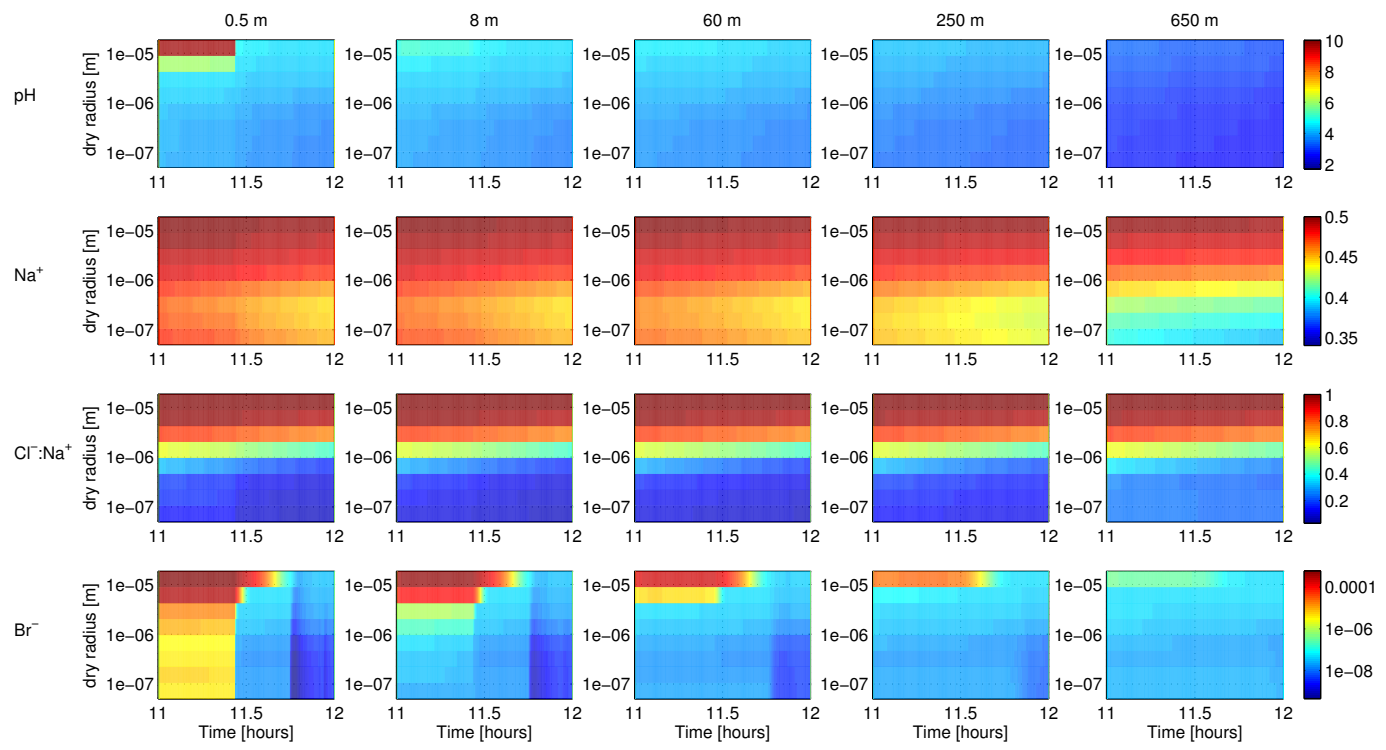

Fig. 5. Seasalt compositional data at different levels through the model column for the base case, low tide, model run. First row is pH. Second and fourth rows are $\mathrm{Na}^{+}$and $\mathrm{Br}^{-}$dry mole fractions, respectively. The third row is the ratio of $\mathrm{Cl}^{-}$and $\mathrm{Na}^{+}$dry mole fractions.
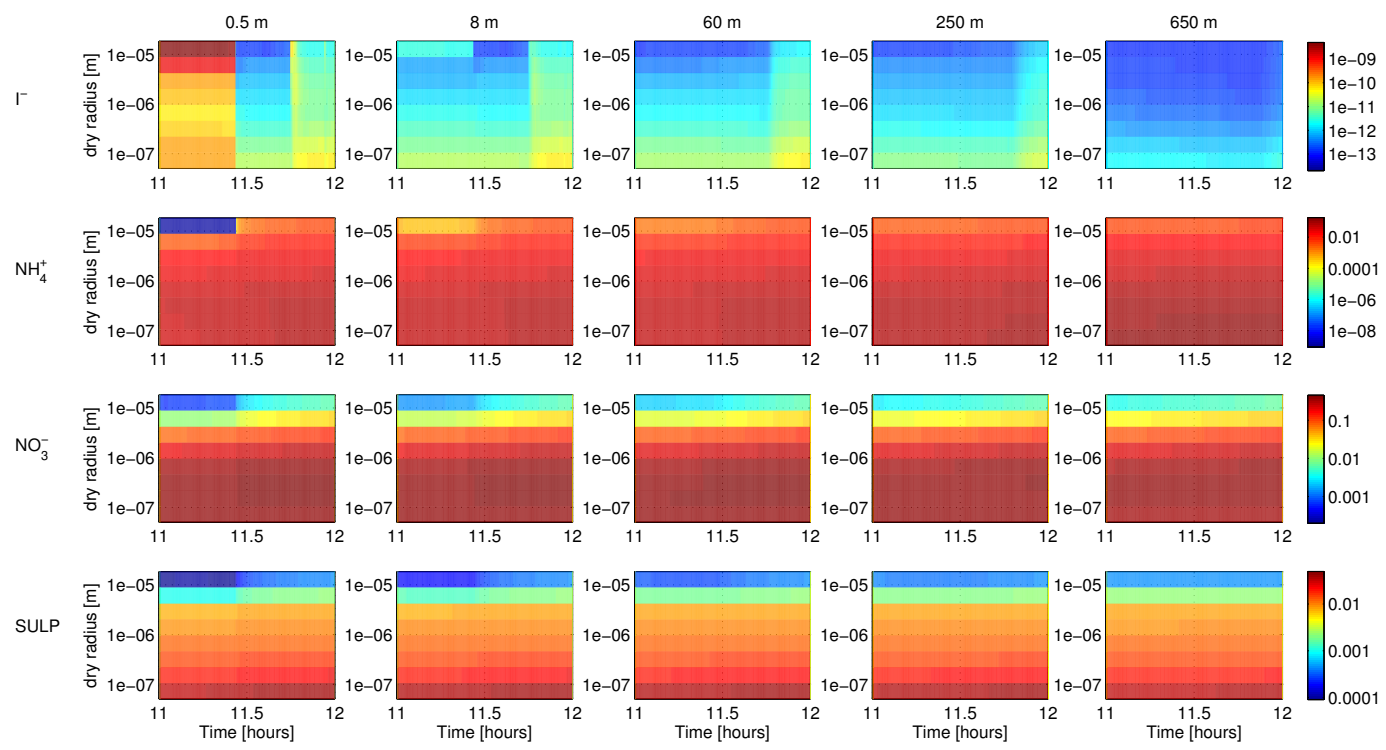

Fig. 6. Seasalt compositional data at different levels through the model column for the base case, low tide, model run. First, second and third rows are $\mathrm{I}^{-}, \mathrm{NH}_{4}^{+}$and $\mathrm{NO}_{3}^{-}$dry mole fractions, respectively. The fourth row is the summed dry mole fraction of $\mathrm{H}_{2} \mathrm{SO}_{4}(\mathrm{aq}), \mathrm{HSO}_{4}^{-}$and $\mathrm{SO}_{4}^{2-}$.

This maximum drops off sharply with height, down to only $520 \mathrm{pmol} \mathrm{mol}^{-1}$ in the next level $(1-3 \mathrm{~m})$, and $25 \mathrm{pmol} \mathrm{mol}^{-1}$ by the fifth level $(10-15 \mathrm{~m})$. The mixing ratio of $\mathrm{I}_{2}$ quickly becomes negligible once it's source term is switched off again (as we would expect without any recycling processes). The reactive iodine species, I, IO, and OIO are almost as short-lived (Figs. 3 and 9), although their vertical gradients are not so drastic. Most iodine from the bursts becomes $\mathrm{IONO}_{2}$ and $\mathrm{I}_{\mathrm{x}} \mathrm{O}_{\mathrm{y}}$, which reach maxima of 1600 and
$780 \mathrm{pmol} \mathrm{mol}^{-1}$ in the lowest level (and 1300 and 550 in the second level), respectively. Vertical mixing leads to the dispersion of these species fairly evenly over the lowest 60 $100 \mathrm{~m}$ of the column, at mixing ratios of $100-50 \mathrm{pmol} \mathrm{mol}^{-1}$.

The LP-DOAS lightpath runs at an average of $8-10 \mathrm{~m}$ above mean sea level. Comparisons with the model column should therefore focus on levels 4 and 5 (6-10 m and $10-15 \mathrm{~m}$ ), although variations in topography along the lightpath means that $I_{2}$ sources could be anything from $2-3 \mathrm{~m}$ to 

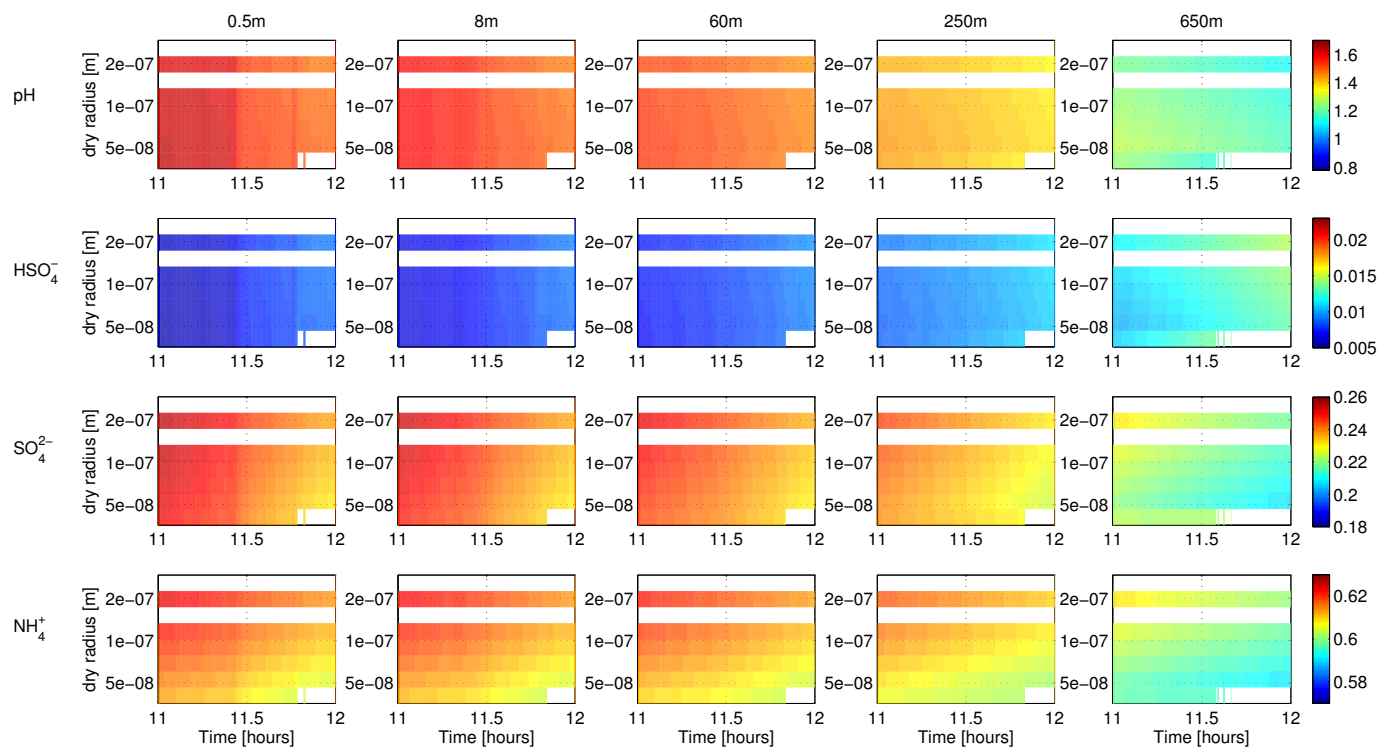

Fig. 7. Non-seasalt compositional data at different levels through the model column for the base case, low tide, model run. First row is $\mathrm{pH}$. Second, third and fourth rows are $\mathrm{HSO}_{4}^{-}, \mathrm{SO}_{4}^{2-}$ and $\mathrm{NH}_{4}^{+}$dry mole fractions, respectively.

$15-20 \mathrm{~m}$ below the lightpath. The model IO mixing ratios peak between $50-20 \mathrm{pmol} \mathrm{mol}^{-1}$ in these levels; 5-2 times the maximum measured IO mixing ratios. The model $\mathrm{I}_{2}$ mixing ratios peak between $70-20 \mathrm{pmol} \mathrm{mol}^{-1}$ in these levels; $3.5-1$ times the maximum measured $\mathrm{I}_{2}$ mixing ratios. OIO was not measured above the detection limit during the day, however the modelled OIO mixing ratios peak between $12-$ $4 \mathrm{pmol} \mathrm{mol}^{-1}$ in these levels, only 3-1 times the detection limit $\left(4 \mathrm{pmol} \mathrm{mol}^{-1}\right)$. The LP-DOAS measurements are averaged over a path of $6.7 \mathrm{~km}$, heterogeneity in the distribution of species across the path could mean that local maxima are much higher than the measured levels. The differences between the modelled and measured mixing ratios could be explained by this heterogeneity, however the $\mathrm{I}_{2}: \mathrm{IO}$ ratio during the $\mathrm{I}_{2}$ bursts is only $1.6-0.8$ at these levels, much less than the average ratio of 3.8 that Mahajan et al. (2009b) calculated from the LP-DOAS measurements. A ratio of 4 is reached at a height of $1-3 \mathrm{~m}$ above the $\mathrm{I}_{2}$ source, at which the $\mathrm{I}_{2}$ and IO are 20-30 times higher than the measurements, suggesting that strong, but spatially limited, $\mathrm{I}_{2}$ sources could reproduce the LP-DOAS measurements if only a couple of metres below the lightpath.

Mixing ratios of reactive chlorine and bromine species drop precipitously within the $\mathrm{I}_{2}$ bursts, as they are converted to $\mathrm{ICl}$ and $\mathrm{IBr}$ by cross-reactions, before increasing equally markedly at the end of the bursts (Figs. 3 and 9). The increases in gas-phase mixing ratios are driven by the extraction of $\mathrm{Cl}^{-}$and $\mathrm{Br}^{-}$from the condensed phase, both from the seasalt mode (Fig. 5) and, less importantly, from the nonseasalt mode (Fig. 8), by iodine. The increase in gas-phase chlorine species is more marked than that of bromine species simply because there is a larger $\mathrm{Cl}^{-}$reservoir in the seasalt mode (which is hardly reduced by the iodine burst).

The first iodine burst also leads to the destruction of around $20 \%$ of the $\mathrm{O}_{3}$ in the lowest level, and consumes practically all $\mathrm{HO}_{\mathrm{x}}$ as well as $\approx 1200 \mathrm{pmol} \mathrm{mol}^{-1}$ of $\mathrm{NO}_{\mathrm{x}}$. These perturbations are also short-lived, though, with mixing replacing the majority of the lost $\mathrm{O}_{3}$ and $\mathrm{NO}_{\mathrm{x}} . \mathrm{HO}_{\mathrm{x}}$ are increased after the burst, boosted by the decrease in $\mathrm{NO}_{\mathrm{x}}$ levels (Fig. 3). The $\mathrm{NO}_{3}^{-}$content of the non-seasalt mode increases during the Iodine bursts (Fig. 8), presumably driven by heterogeneous reactions of $\mathrm{IONO}_{2}$ with the non-seasalt mode, although it should be noted that the $\mathrm{NO}_{3}^{-}$of the seasalt mode does not increase at the same time (Fig. 6).

\section{$4.2 \quad I_{2}$ recycling}

Mahajan et al. (2009b) reported an increase in $\mathrm{NO}_{3}$ mixing ratios, to $\approx 10 \mathrm{pmol} \mathrm{mol}^{-1}$, when using the $\mathrm{I}_{2}$ recycling reaction (Reaction $\mathrm{R} 1$ ). Without this reaction an increase in $\mathrm{NO}_{3}$ is observed in the current work, but only to $\approx 1 \mathrm{pmol} \mathrm{mol}^{-1}$ (Fig. 9). Reaction (R1) has been included in the current model to examine the changes in iodine compound mixing ratios and to investigate if other changes in the mixed-phase chemistry occur. This version of the model was used to simulate low tide at Roscoff, initialised from the same starting mixing ratios as the base case Roscoff runs.

$\mathrm{I}_{2}$ mixing ratios were found to be higher than the base case (reaching $2500 \mathrm{pmol} \mathrm{mol}^{-1}$ in the lowest level), and tail off more gently after the end of the $\mathrm{I}_{2}$ burst. This increases IO, OIO, and $\mathrm{I}_{\mathrm{x}} \mathrm{O}_{\mathrm{y}}$ mixing ratios (Fig. 10), while peak $\mathrm{IONO}_{2}$ mixing ratios drastically decrease to 

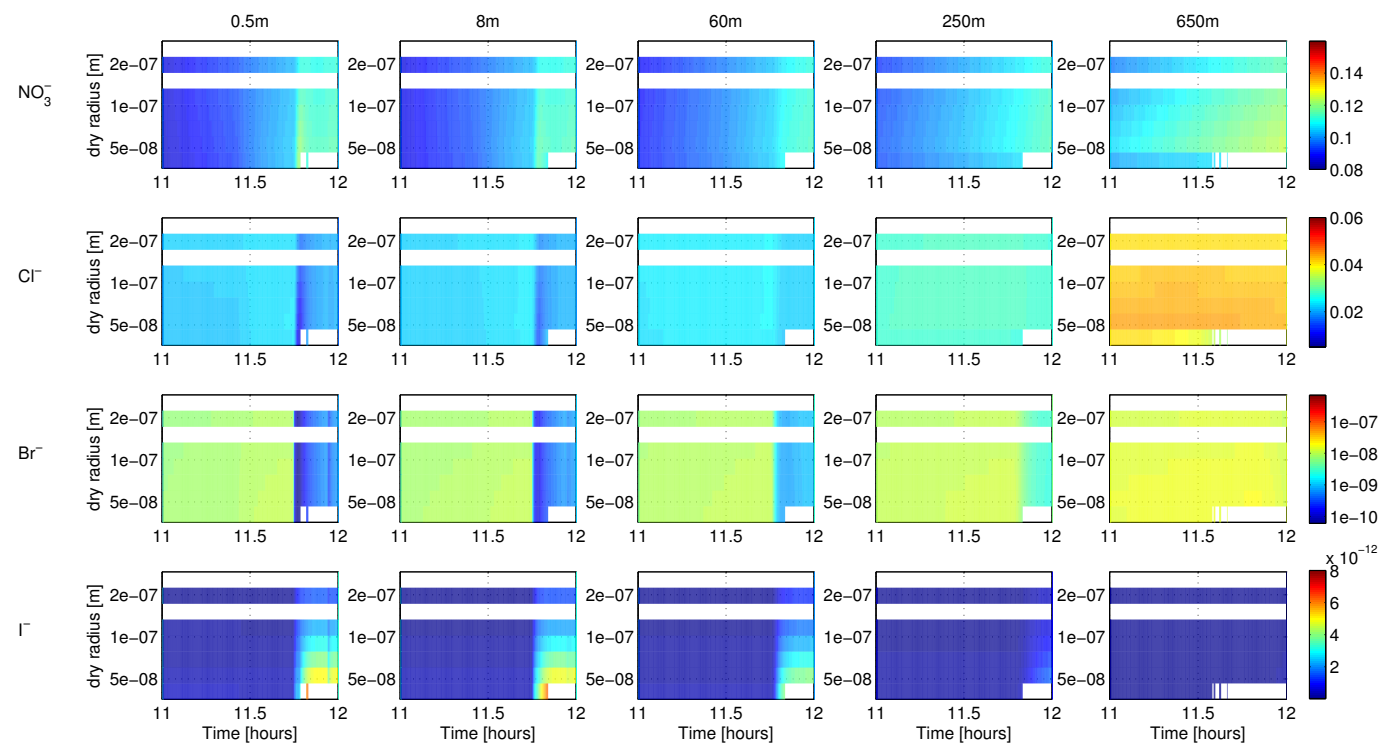

Fig. 8. Non-seasalt compositional data at different levels through the model column for the base case, low tide, model run. First, second, third and fourth rows are $\mathrm{NO}_{3}^{-}, \mathrm{Cl}^{-}, \mathrm{Br}^{-}$and $\mathrm{I}^{-}$dry mole fractions, respectively.
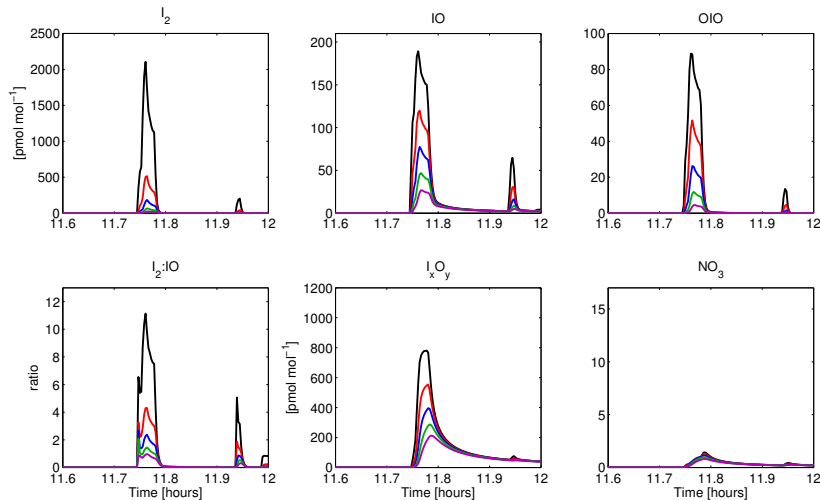

Fig. 9. Mixing ratios of $\mathrm{I}_{2}, \mathrm{IO}, \mathrm{OIO}, \mathrm{I}_{\mathrm{x}} \mathrm{O}_{\mathrm{y}}, \mathrm{NO}_{3}$, and ratio of $\mathrm{I}_{2}: \mathrm{IO}$, in the lowest five layers of the model column for the base case, low tide, model run. Black, red, blue, green, and purple lines represent levels with their centres at $0.5,2,4.5,8$ and $12.5 \mathrm{~m}$, respectively.

$\approx 210 \mathrm{pmol} \mathrm{mol}^{-1}$ (see Supplement). At the column height of 6-15 m peak IO increases to $65-45 \mathrm{pmol} \mathrm{mol}^{-1}$, peak $\mathrm{I}_{2}$ to 220-140 $\mathrm{pmol} \mathrm{mol}^{-1}$, and peak OIO to $20-10 \mathrm{pmol} \mathrm{mol}^{-1}$. $\mathrm{I}_{2}: \mathrm{IO}$ ratios at this height increases to $3.5-3$, which drops away to $2-1$ after the $I_{2}$ burst. This is much closer to the LPDOAS measurements, as found by Mahajan et al. (2009b).

$\mathrm{NO}_{3}$ increases to $\approx 10 \mathrm{pmol} \mathrm{mol}^{-1}$, consistent with the finding of Mahajan et al. (2009b), and may be a measurable diagnostic for $I_{2}$ recycling in the ambient atmosphere. This increase changes the response of $\mathrm{NO}_{2}$ mixing ratios to the $\mathrm{I}_{2}$ burst, which dramatically increases by $500 \mathrm{pmol} \mathrm{mol}^{-1}$ during the burst, rather than decreasing by $100 \mathrm{pmol} \mathrm{mol}^{-1}$ as the basic model does (see
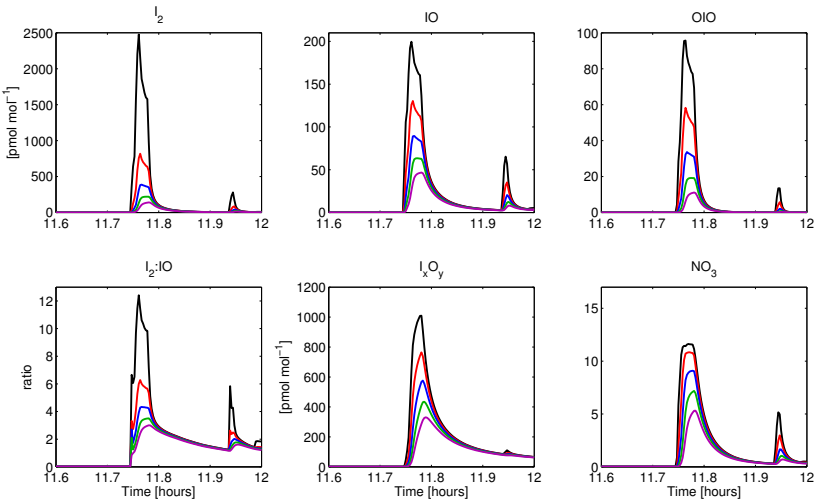

Fig. 10. Mixing ratios of $\mathrm{I}_{2}, \mathrm{IO}, \mathrm{OIO}, \mathrm{I}_{\mathrm{x}} \mathrm{O}_{\mathrm{y}}, \mathrm{NO}_{3}$, and ratio of $\mathrm{I}_{2}: \mathrm{IO}$, in the lowest five layers of the model column for the $\mathrm{I}_{2}$ recycling, low tide, model run. Black, red, blue, green, and purple lines represent levels with their centres at $0.5,2,4.5,8$ and $12.5 \mathrm{~m}$, respectively.

Supplement). The decrease in $\mathrm{IONO}_{2}$ mixing ratios also reduces the depletion of $\mathrm{Cl}^{-}$and $\mathrm{Br}^{-}$from the condensedphase via heterogeneous reactions. The reduction of these heterogeneous reactions also decreases the accumulation of $\mathrm{NO}_{3}^{-}$in the non-seasalt mode during the $\mathrm{I}_{2}$ bursts. This reduces the peak $\mathrm{NO}_{3}^{-}$dry mole fraction from 0.13 to 0.11 (Figs. 8 and 11), and so reduces the growth of the non-seasalt mode due to the uptake of nitrate (Figs. 4 and 11). Our model does not, however, deal with the condensation of $\mathrm{I}_{\mathrm{x}} \mathrm{O}_{\mathrm{y}}$ species, the increase of which could compensate for this reduction in particle growth. However it should also be noted that nucleation, which is thought to be an appreciable 

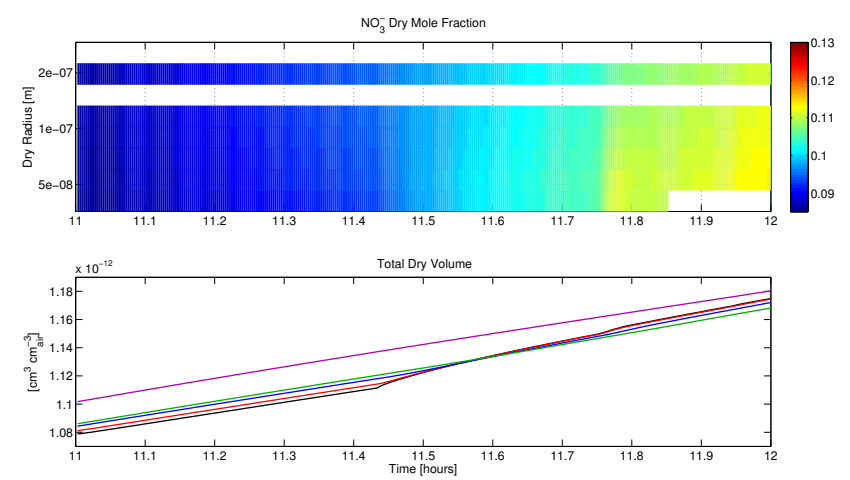

Fig. 11. Non-seasalt aerosol properties for the $I_{2}$ recycling, low tide, model run. Top panel is the dry mole fraction of $\mathrm{NO}_{3}^{-}$at a height of $0.5 \mathrm{~m}$. Bottom panel is total dry volume of the nonseasalt mode at heights of $0.5,8,60,250$ and $650 \mathrm{~m}$ (black, red, blue, green, and purple lines, respectively).

sink of the $\mathrm{I}_{\mathrm{x}} \mathrm{O}_{\mathrm{y}}$ species, is also not accounted for in the model.

\subsection{Low photolysis}

The testcases presented above all use near clear-sky conditions - the weather conditions at Roscoff were more mixed, however, so we have conducted an investigation into the influence of photolytic rates on the iodine chemistry. To study this effect we have chosen to use the photolysis data from 14 September 2006, when cloud cover reduced the actinic flux by $40-50 \%$ between 11:00 a.m. and 12:00 p.m. (see Supplement for the actinic flux diurnal profile for this day). We have also reduced the midday peak photolysis rates for $\mathrm{I}_{2} \mathrm{O}_{2}$, $\mathrm{I}_{2} \mathrm{O}_{3}$ and $\mathrm{I}_{2} \mathrm{O}_{4}$ by $50 \%$ to 0.03 to match the reductions in the rest of the photolysis rates. We have rerun both the standard chemistry and the $\mathrm{I}_{2}$ recycling schemes for the low tide testcase with these new photolysis rates.

Reducing the photolysis rates leads to increases in $\mathrm{I}_{2}$ and $\mathrm{NO}_{3}$ mixing ratios, while the mixing ratios of $\mathrm{IO}, \mathrm{OIO}$, and $\mathrm{I}_{\mathrm{x}} \mathrm{O}_{\mathrm{y}}$ have decreased (see Fig. 12). These changes are most pronounced in the lowest model level for all of these species except $\mathrm{I}_{2}$, for which the proportional change increases with height (this is to be expected, as it is the $I_{2}$ source term which most determines it's mixing ratio in the lowest level, while for the other species the reduction of their production rates from, ultimately, the photolysis of $\mathrm{I}_{2}$ will greatly reduce their mixing ratios close to the $I_{2}$ source). At levels 4 and 5 the peak mixing ratios of $\mathrm{I}_{2}$ have increased to around 120-55 and 320-210 $\mathrm{pmol} \mathrm{mol}^{-1}$ for the standard chemistry and $\mathrm{I}_{2}$ recycling schemes, respectively. These mixing ratios are some $100-50 \%$ higher than the $\mathrm{I}_{2}$ mixing ratios at higher photolysis rates. Conversely, the peak IO mixing ratios at these model levels are around 40-25 and 50$35 \mathrm{pmol} \mathrm{mol}^{-1}$, respectively for the standard chemistry and $\mathrm{I}_{2}$ recycling schemes. These mixing ratios are within the
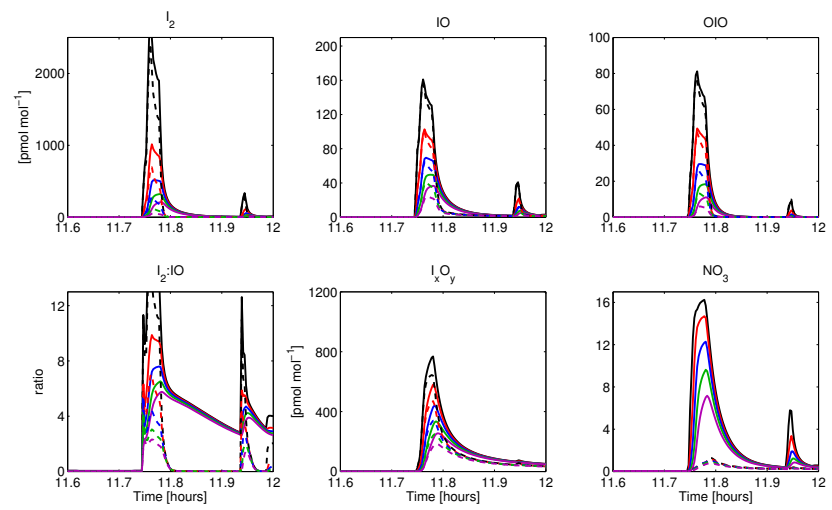

Fig. 12. Mixing ratios of $\mathrm{I}_{2}, \mathrm{IO}, \mathrm{OIO}, \mathrm{I}_{\mathrm{x}} \mathrm{O}_{\mathrm{y}}, \mathrm{NO}_{3}$, and ratio of $\mathrm{I}_{2}: \mathrm{IO}$, in the lowest five layers of the model column for the two low photo, low tide, model runs. Dashed and solid lines are, respectively, for the standard chemistry scheme and the $\mathrm{I}_{2}$ recycling scheme. Black, red, blue, green, and purple lines represent levels with their centres at $0.5,2,4.5,8$ and $12.5 \mathrm{~m}$, respectively.

range of the peak IO mixing ratios at higher photolysis rates; similarly the mixing ratios of OIO at these levels (13-6 and 18-11 $\mathrm{pmol} \mathrm{mol}^{-1}$, respectively for the standard chemistry and $\mathrm{I}_{2}$ recycling schemes) are much the same as they are for the higher photolysis model runs.

The increase in $\mathrm{I}_{2}$ leads to an increase in $\mathrm{I}_{2}$ :IO ratio; reaching maximum values in levels 4 and 5 of 4.2-2.3 and 5.8-6.5 in the standard chemistry and $\mathrm{I}_{2}$ recycling testcases, respectively. This increase brings the $\mathrm{I}_{2}: \mathrm{IO}$ ratio of the standard chemistry testcase close to that reported by Mahajan et al. (2009b). The peak $I_{2}: I O$ ratio in the $I_{2}$ recycling testcase is at the higher end of the reported $\mathrm{I}_{2}: \mathrm{IO}$ ratios. As before this ratio drops off more slowly than in the standard chemistry testcase, remaining above 2.5 after the first $\mathrm{I}_{2}$ burst (and between 4.5-3.0 for the majority of this period).

\subsection{Comparison with in-situ measurements}

The $\mathrm{I}_{2}$ emission scenario used for the low-tide model runs above is most useful for studying the LP-DOAS measurements because of the strong, concentrated $\mathrm{I}_{2}$ burst. However it is not as useful for comparison with the in-situ measurements of IO (Whalley et al., 2007) and $\mathrm{I}_{2}$ (Leigh et al., 2010) because of weakness of the two $\mathrm{I}_{2}$ emission bursts close to Roscoff (blue line, Fig. 2) - our model does not consider the local mixing of air masses that is included in footprint emission models (cf. Leigh et al., 2010), which would smooth out local variations in $\mathrm{I}_{2}$ emissions. For example, the second model trajectory chosen for this study (red line, Fig. 2), which arrives into Roscoff just over an hour later than the first trajectory, has far higher emissions close to Roscoff, due to a combination of the direction of trajectory and the spatial variation of seaweed beds around Roscoff. Local mixing of air masses would smooth out the differences in chemical composition between the two model trajectories. 
We have used these two emission scenarios for making a comparison with the in-situ measurements of $\mathrm{IO}$ and $\mathrm{I}_{2}$ made at Roscoff. We have run the model along the second emission trajectory with both the standard chemistry scheme, and with the $I_{2}$ recycling reaction, as well as with both the high photolysis rates from the 23 September 2006, and the lower photolysis rates from the 14 September 2006. The vertical profiles of $\mathrm{IO}, \mathrm{I}_{2}, \mathrm{OIO}$, and $\sum\left(\mathrm{NO}_{3}+\mathrm{N}_{2} \mathrm{O}_{5}\right)$, up to a height of $20 \mathrm{~m}$, at the end of the model runs for these four model setups, as well as those for the equivalent four model setups run over the original $\mathrm{I}_{2}$ emission trajectory, are shown in Fig. 13.

The mixing ratios for all these gas-phase species are highest for the second emission scenario, with the $\mathrm{I}_{2}$ recycling scheme (green lines). The highest mixing ratios for IO, OIO and $\sum\left(\mathrm{NO}_{3}+\mathrm{N}_{2} \mathrm{O}_{5}\right)$ occur in the high photolysis scenario (green dashed lines), while the maximum $\mathrm{I}_{2}$ mixing ratio occurs in the low photolysis scenario (green solid line). In neither case, however, does the model match the maximum measured mixing ratios of $\mathrm{I}_{2}$ and $\mathrm{IO}$ from the RHaMBLe campaign, which were $50 \mathrm{pmol} \mathrm{mol}^{-1}$ and $30 \mathrm{pmol} \mathrm{mol}^{-1}$, respectively (McFiggans et al., 2010). Indeed the maximum modelled mixing ratios are only reach $30-60 \%$ of the maximum measured mixing ratios. Incorporation of local mixing into the model, to smooth the heterogeneity of the seaweed beds, would help increase the modelled mixing ratios, but probably not by the factor of 2-3 needed to match the maximum measured values.

The $\mathrm{I}_{2}$ mixing ratios in the standard chemistry model runs (red and black lines) are very low; without the recycling mechanism $\mathrm{I}_{2}$ does not persist for long, and so the $\mathrm{I}_{2}$ mixing ratio at Roscoff is zero for the second emission scenario (red lines), while the mixing ratio for the first emission scenario (black lines) reaches $5 \mathrm{pmol} \mathrm{mol}^{-1}$ in the lowest model level (dropping away sharply above that level) only because of the small $\mathrm{I}_{2}$ source immediately before Roscoff. With the recycling mechanism the $I_{2}$ mixing ratio for the first emission scenario (blue lines) does increase, to 5-6 $\mathrm{pmol} \mathrm{mol}^{-1}$ above the bottom few metres of the column; however this is still below the detection limit of the BBCRDS (about 10$15 \mathrm{pmol} \mathrm{mol}^{-1}$ ). This variability in $\mathrm{I}_{2}$ loadings fits well with the $I_{2}$ measurements made at Roscoff - where $I_{2}$ mixing ratios were above the detection limit of the BBCRDS on only 4 out of the 10 days of measurements (McFiggans et al., 2010).

IO mixing ratios show less variation between the different model runs. The model runs using the second emission profile (green and red lines) are higher than those of the model runs using the first emission profile (blue and black lines); but in all cases the mixing ratios are higher than the detection limit of the FAGE LIF (about $0.3 \mathrm{pmol} \mathrm{mol}^{-1}$ ). This again fits well with the IO measurements made during the campaign, where there was less variation than in the $I_{2}$ mixing ratios, and IO mixing ratios were above the detection limit for 14 out of the 20 days of measurements (with a high dependence on the wind direction McFiggans et al., 2010).
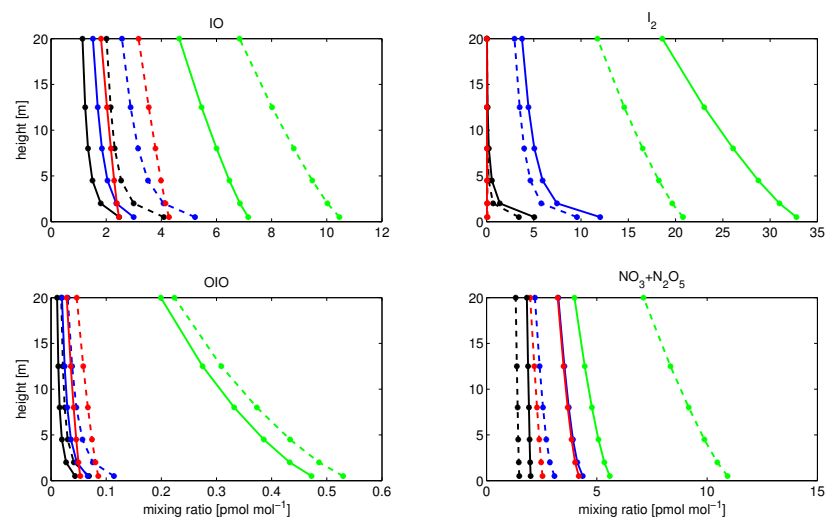

Fig. 13. Mixing ratios of $\mathrm{I}_{2}, \mathrm{IO}, \mathrm{OIO}$, and $\sum \mathrm{NO}_{3}+\mathrm{N}_{2} \mathrm{O}_{5}$ in the lowest $20 \mathrm{~m}$ of the model column (data points indicate the centres of model levels). Dashed and solid lines indicate, respectively, the standard and low photolysis testcases. Black and blue lines indicate the base $\mathrm{I}_{2}$ emission testcases; green and red lines indicate the closer $\mathrm{I}_{2}$ emission testcases. Red and black lines indicate the standard chemistry testcases; green and blue lines indicate the $I_{2}$ recycling testcases.

$\sum\left(\mathrm{NO}_{3}+\mathrm{N}_{2} \mathrm{O}_{5}\right)$ mixing ratios are above the detection limit of the BBCEAS instrument $\left(0.09-0.25 \mathrm{pmol} \mathrm{mol}^{-1}\right.$ Langridge et al., 2008); though no daytime measurements were made during the RHaMBLe campaign, so we cannot make comparisons with in-situ measurements. $\mathrm{NO}_{3}$ photolyzes rapidly, so for most model setups the mixing ratio of $\sum\left(\mathrm{NO}_{3}+\mathrm{N}_{2} \mathrm{O}_{5}\right)$ is higher in the low photolysis scenarios (solid lines). For the second emission scenario, with the $\mathrm{I}_{2}$ recycling mechanism (green lines), we observe that the $\sum\left(\mathrm{NO}_{3}+\mathrm{N}_{2} \mathrm{O}_{5}\right)$ mixing ratio increases with increasing photolysis rates. This suggests that we should observe quite large daytime spikes in $\sum\left(\mathrm{NO}_{3}+\mathrm{N}_{2} \mathrm{O}_{5}\right)$ mixing ratios if the proposed $\mathrm{I}_{2}$ mechanism is in operation.

\subsection{Simulated BrO concentrations}

$\mathrm{BrO}$ mixing ratios are very low throughout the model run at around $2-4 \times 10^{-3} \mathrm{pmol} \mathrm{mol}^{-1}$. Most measurements of daytime $\mathrm{BrO}$ made during the RHaMBLe campaign were around 1-2 pmol mol${ }^{-1}$ with a maximum of $7 \mathrm{pmol} \mathrm{mol}^{-1}$ (Mahajan et al., 2009a). In the base case simulation most gaseous bromine in the model is in the form of $\mathrm{BrNO}_{2}$ (4.6$\left.4.8 \mathrm{pmol} \mathrm{mol}^{-1}\right)$ and $\mathrm{BrCl}\left(1-1.2 \mathrm{pmol} \mathrm{mol}^{-1}\right)$, with the majority of the rest in $\mathrm{BrONO}_{2}$ and $\mathrm{HBr}$, at $0.12-0.2$ and $0.07-$ $0.16 \mathrm{pmol} \mathrm{mol}^{-1}$, respectively (Fig. 3). The total bromine in the gas-phase ranges from $6.0-6.4 \mathrm{pmol} \mathrm{mol}^{-1}$, having accumulated gradually over the Channel run as fresh seasalt comes into contact with polluted air (condensed-phase bromine content is $0.14 \mathrm{pmol} \mathrm{mol}^{-1}$ immediately above the sea-surface, dropping to $0.0002 \mathrm{pmol} \mathrm{mol}^{-1}$ with height, and when over the exposed intertidal region). 

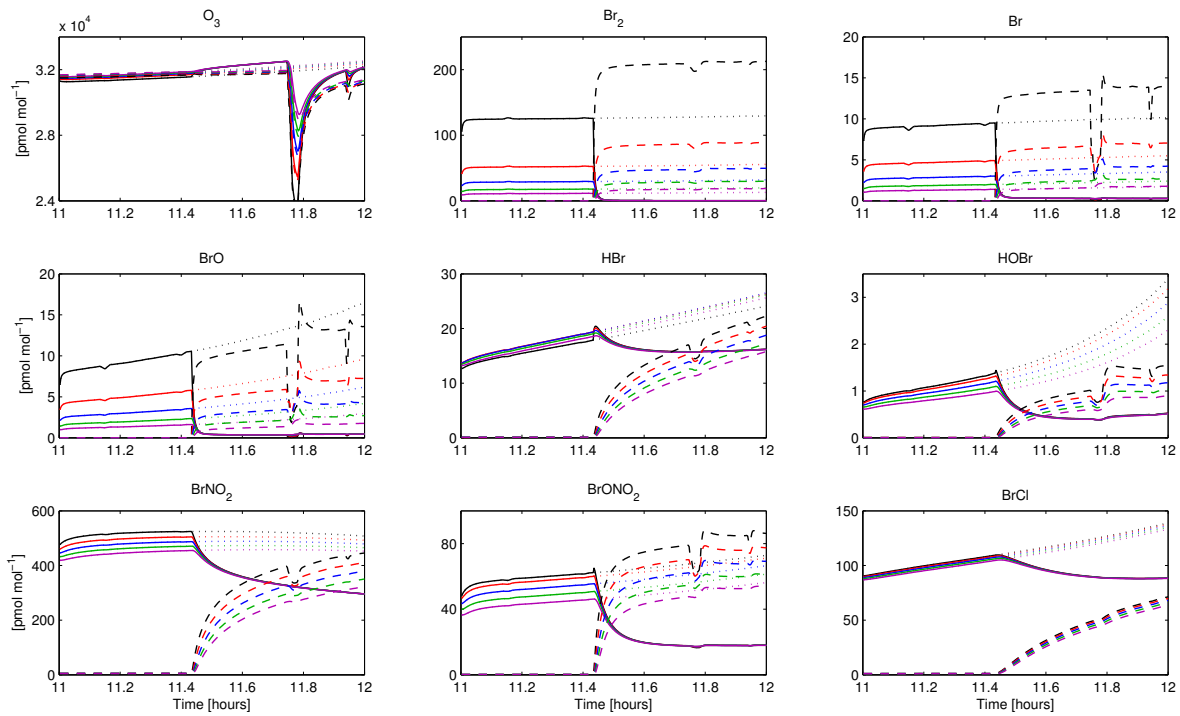

Fig. 14. Mixing ratios of $\mathrm{O}_{3}$ and the major bromine compounds, in the lowest five layers of the model column. Black, red, blue, green, and purple lines represent levels with their centres at $0.5,2,4.5,8$ and $12.5 \mathrm{~m}$, respectively. Solid and dotted lines represent mixing ratios from the model runs with a sea based $\mathrm{Br}_{2}$ source (solid lines are for the low-tide scenario, dotted lines for the high-tide scenario). Dashed lines represent mixing ratios from the low-tide model run with a beach based $\mathrm{Br}_{2}$ source.

With an average daytime maximum $\mathrm{BrO}$ mixing ratio of only $3 \times 10^{-3} \mathrm{pmol} \mathrm{mol}^{-1}$, it is a factor of 1000 less than the BrO observations made at Roscoff. Mahajan et al. (2009a) observed that the measured $\mathrm{BrO}$ mixing ratios could be replicated in a polluted environment if there was a total bromine loading of $200 \mathrm{pmol} \mathrm{mol}^{-1}$, otherwise current chemistry schemes could not explain the $\mathrm{BrO}$ observations. They used a simple gas-phase box-model for this study, forced with an initial content of $100 \mathrm{pmol} \mathrm{mol}^{-1} \mathrm{Br}_{2}$. To investigate what kind of bromine sources needed to replicate the $\mathrm{BrO}$ measurements three testcases were performed with $\mathrm{Br}_{2}$ sources. The first two use a $\mathrm{Br}_{2}$ source term from the sea of $3 \times 10^{10}$ molecules $\mathrm{cm}^{-2} \mathrm{~s}^{-1}$ (which runs from the start of the Channel leg and across the sea-section of the Roscoff legs), one using the Roscoff high-tide scenario, the other the low-tide scenario. The third testcase is initialised using the same Channel leg as the original testcases, but has a constant $\mathrm{Br}_{2}$ source term across the intertidal zone of $5 \times 10^{10}$ molecules $\mathrm{cm}^{-2} \mathrm{~s}^{-1}$ (using the low-tide scenario only).

Ozone and bromine compound mixing ratios for the lowest 5 levels from each of the three model runs are shown in Fig. 14. $\mathrm{Br}_{2}$ mixing ratios are, as would be expected, higher in the beach $\mathrm{Br}_{2}$ source term scenario. $\mathrm{BrO}$ mixing ratios are, however, very similar between the two different source terms, around $8-15 \mathrm{pmol} \mathrm{mol}^{-1}$ in the lowest level, and $2-4 \mathrm{pmol} \mathrm{mol}^{-1}$ between $8-15 \mathrm{~m}$ height. This is due to the build up of reservoir bromine compounds during the Channel leg with a sea $\mathrm{Br}_{2}$ source term. The responses of $\mathrm{Br}_{2}, \mathrm{Br}$, and $\mathrm{BrO}$ to changes in the $\mathrm{Br}_{2}$ source term are very rapid. All other bromine compounds show a steady increase in mixing ratio with time (with a vertical gradient) when the $\mathrm{Br}_{2}$ source is active, but then drop off when the source is switched off (as vertical mixing becomes the dominant process and brings their mixing ratios in line with the bulk of the vertical column). The majority of gas-phase bromine is still locked up in $\mathrm{BrNO}_{2}$, which reaches $500 \mathrm{pmol} \mathrm{mol}^{-1}$ in the lowest level after $5.5 \mathrm{~h}$ of $\mathrm{Br}_{2}$ emissions, and increases rapidly to $400 \mathrm{pmol} \mathrm{mol}^{-1}$ when the beach $\mathrm{Br}_{2}$ source term is switched on.

The $\mathrm{I}_{2}$ bursts have a very strong effect on the $\mathrm{BrO}$ mixing ratios, reducing $\mathrm{BrO}$ by $5 \mathrm{pmol} \mathrm{mol}^{-1}$ within the centre of the burst. The rapid response of $\mathrm{BrO}$ to changes in source term, as well as to changes in halogen chemistry, suggests that a very localised reactive bromine source is needed to explain the observations.

\section{Conclusions}

LP-DOAS IO and OIO observations (or lack thereof) are likely the result of localised emissions from macroalgae, which are diluted with cleaner air to get average mixing ratios. LP-DOAS $\mathrm{I}_{2}$ observations can be explained with current chemistry schemes, if the $\mathrm{I}_{2}$ source term is strong and within a few metres of the LP-DOAS lightpath. However the observations are better matched by the model using a recycling reaction to convert $\mathrm{IONO}_{2}$ back into $\mathrm{I}_{2}$. Additionally, the insitu measurements of $\mathrm{I}_{2}$ made during the campaign can only be explained by incorporating a recycling mechanism for $\mathrm{I}_{2}$. 
Targeted observations should be able to distinguish between these two scenarios. During $I_{2}$ bursts in the polluted marine environment, it would be expected that localised increases in $\mathrm{I}_{2}$ and $\mathrm{IO}$, coupled with decreases in the $\mathrm{NO}: \mathrm{NO}_{2}$ ratio and growth of non-seasalt aerosol volumes would occur. If Reaction (R1) is atmospherically important, $\mathrm{NO}_{3}$ and $\mathrm{NO}_{2}$ mixing ratios would markedly increase, while $\mathrm{NO}_{\mathrm{x}}$ and $\mathrm{NO}_{\mathrm{y}}$ would not change greatly. If recycling does not play an atmospheric role then a small increase in $\mathrm{NO}_{3}$, accompanied by a drop in $\mathrm{NO}_{2}$ and $\mathrm{NO}_{\mathrm{x}}$ and a substantial increase in $\mathrm{NO}_{\mathrm{y}}$ (mainly attributable to an increase in $\mathrm{IONO}_{2}$ ) should be observed. At the same time a substantial, and measurable, increase in nitrate fraction, and greater increase in mass loading, of the non-seasalt aerosol mode would occur.

LP-DOAS BrO measurements are higher than could be explained purely with a sea-salt bromine source. Unknown, extremely localised, emissions of reactive bromine could be the source for these measurements.

\section{Supplementary material related to this article is available online at: http://www.atmos-chem-phys.net/11/979/2011/ acp-11-979-2011-supplement.zip.}

Acknowledgements. This work was carried out within the UK NERC-funded Reactive Halogens in the Marine Boundary Layer (RHaMBLe, NE/D006570/1) and EU-funded Marine Aerosol Production (MAP, GOCE 018332) projects. Our thanks to Rolf Sander and anonymous referee for their comments which have helped improve this manuscript.

Edited by: R. von Glasow

\section{References}

Allan, B. J., McFiggans, G. B., Plane, J. M. C., and Coe, H.: Observations of iodine monoxide in the remote boundary layer, J. Geophys. Res., 105, 14363-14369, 2000.

ApSimon, H. M., Barker, B. M., and Kayin, S.: Modelling studies of the atmospheric release and transport of ammonia in anticyclonic episodes, Atmos. Environ., 28, 665-678, 1994.

Bloss, W. J., Lee, J. D., Johnson, G. P., Sommariva, R., Heard, D. E., Saiz-Lopez, A., Plane, J. M. C., McFiggans, G., Coe, H., Flynn, M., Williams, P., Rickard, A. R., and Fleming, Z. L.: Impact of halogen monoxide chemistry upon boundary layer $\mathrm{OH}$ and $\mathrm{HO}_{2}$ concentrations at a coastal site, Geophys. Res. Lett., 32, L06814, doi:10.1029/2004GL022084, 2005.

Carpenter, L. J., Sturges, W. T., Penkett, S. A., Liss, P. S., Alicke, B., Heibestreit, K., and Platt, U.: Short-lived alkyl iodides and bromides at Mace Head, Ireland: links to biogenic sources and halogen oxide production, J. Geophys. Res., 104, 1679-1689, 1999.

Davis, D., Crawford, J., Liu, S., McKeen, S., Bandy, A., Thornton, D., Rowland, F., and Blake, D.: Potential impact of iodine on tropospheric levels of ozone and other critical oxidants, J. Geophys. Res., 101, 2135-2147, 1996.
Edwards, G. D. and Monks, P. S.: Performance of a singlemonochromator diode array spectroradiometer for the determination of actinic flux and atmospheric photolysis frequencies, $\mathrm{J}$. Geophys. Res., 108, 8546, doi:10.1029/2002JD002844, 2003.

Gómez Martín, J. C., Spietz, P., and Burrows, J. P.: Kinetic and mechanistic studies of the $\mathrm{I}_{2} / \mathrm{O}_{3}$ photochemistry, The journal of physical chemistry. A, 111, 306-20, doi:10.1021/jp061186c, 2007.

Gómez Martín, J. C., Ashworth, S. H., Mahajan, A. S., and Plane, J. M. C.: Photochemistry of OIO: Laboratory study and atmospheric implications, Geophys. Res. Lett., 36, L09802, doi:10.1029/2009GL037642, 2009.

Gong, S. L.: A parameterization of sea-salt aerosol source function for sub- and super-micron particles, Global Biogeochem. Cy., 17, 1097, doi:10.1029/2003GB002079, 2003.

Heard, D. E., Read, K. A., Methven, J., Al-Haider, S., Bloss, W. J., Johnson, G. P., Pilling, M. J., Seakins, P. W., Smith, S. C., Sommariva, R., Stanton, J. C., Still, T. J., Ingham, T., Brooks, B., De Leeuw, G., Jackson, A. V., McQuaid, J. B., Morgan, R., Smith, M. H., Carpenter, L. J., Carslaw, N., Hamilton, J., Hopkins, J. R., Lee, J. D., Lewis, A. C., Purvis, R. M., Wevill, D. J., Brough, N., Green, T., Mills, G., Penkett, S. A., Plane, J. M. C., Saiz-Lopez, A., Worton, D., Monks, P. S., Fleming, Z., Rickard, A. R., Alfarra, M. R., Allan, J. D., Bower, K., Coe, H., Cubison, M., Flynn, M., McFiggans, G., Gallagher, M., Norton, E. G., O'Dowd, C. D., Shillito, J., Topping, D., Vaughan, G., Williams, P., Bitter, M., Ball, S. M., Jones, R. L., Povey, I. M., O'Doherty, S., Simmonds, P. G., Allen, A., Kinnersley, R. P., Beddows, D. C. S., Dall'Osto, M., Harrison, R. M., Donovan, R. J., Heal, M. R., Jennings, S. G., Noone, C., and Spain, G.: The North Atlantic Marine Boundary Layer Experiment(NAMBLEX). Overview of the campaign held at Mace Head, Ireland, in summer 2002, Atmos. Chem. Phys., 6, 2241-2272, doi:10.5194/acp-6-2241-2006, 2006.

Hoffmann, T., O’Dowd, C. D., and Seinfeld, J. H.: Iodine oxide homogeneous nucleation: An explanation for coastal new particle formation, Geophys. Res. Lett., 28, 1949-1952, 2001.

Hoppel, W. A., Caffrey, P., and Frick, G. M.: Addition of Vertical Velocity to a One-Dimensional Aerosol and Trace Gas Model, Naval Research Laboratory, Washington DC, NRL/MR/722805-8852, 2005.

Kaltsoyannis, N. and Plane, J. M. C.: Quantum chemical calculations on a selection of iodine-containing species (IO, $\mathrm{OIO}, \mathrm{INO}_{3},(\mathrm{IO})_{2}, \mathrm{I}_{2} \mathrm{O}_{3}, \mathrm{I}_{2} \mathrm{O}_{4}$ and $\left.\mathrm{I}_{2} \mathrm{O}_{5}\right)$ of importance in the atmosphere, Phys. Chem. Chem. Phys., 10, 1723-1733, doi:10.1039/b715687c, 2008.

Langridge, J. M., Ball, S. M., Shillings, A. J. L., and Jones, R. L.: A broadband absorption spectrometer using light emitting diodes for ultrasensitive, in situ trace gas detection, Rev. Sci. Instrum., 79, 123110, doi:10.1063/1.3046282, 2008.

Leigh, R. J., Ball, S. M., Whitehead, J., Leblanc, C., Shillings, A. J. L., Mahajan, A. S., Oetjen, H., Lee, J. D., Jones, C. E., Dorsey, J. R., Gallagher, M., Jones, R. L., Plane, J. M. C., Potin, P., and McFiggans, G.: Measurements and modelling of molecular iodine emissions, transport and photodestruction in the coastal region around Roscoff, Atmos. Chem. Phys., 10, 11823-11838, doi:10.5194/acp-10-11823-2010, 2010.

Lowe, D., Topping, D., and McFiggans, G.: Modelling multi-phase halogen chemistry in the remote marine boundary layer: inves- 
tigation of the influence of aerosol size resolution on predicted gas- and condensed-phase chemistry, Atmos. Chem. Phys., 9, 4559-4573, doi:10.5194/acp-9-4559-2009, 2009.

Mahajan, A. S., Oetjen, H., Lee, J. D., Saiz-Lopez, A., McFiggans, G. B., and Plane, J. M.: High bromine oxide concentrations in the semi-polluted boundary layer, Atmos. Environ., 43, 3811-3818, doi:10.1016/j.atmosenv.2009.05.033, 2009a.

Mahajan, A. S., Oetjen, H., Saiz-Lopez, A., Lee, J. D., McFiggans, G. B., and Plane, J. M. C.: Reactive iodine species in a semi-polluted environment, Geophys. Res. Lett., 36, L16803, doi:10.1029/2009GL038018, 2009b.

Mahajan, A. S., Plane, J. M. C., Oetjen, H., Mendes, L., Saunders, R. W., Saiz-Lopez, A., Jones, C. E., Carpenter, L. J., and McFiggans, G. B.: Measurement and modelling of tropospheric reactive halogen species over the tropical Atlantic Ocean, Atmos. Chem. Phys., 10, 4611-4624, doi:10.5194/acp-10-46112010, 2010.

McFiggans, G., Plane, J. M. C., Allan, B. J., Carpenter, L. J., Coe, H., and O'Dowd, C.: A modeling study of iodine chemistry in the marine boundary layer, J. Geophys. Res., 105, 1437114385, 2000.

McFiggans, G., Coe, H., Burgess, R., Allan, J., Cubison, M., Alfarra, M. R., Saunders, R., Saiz-Lopez, A., Plane, J. M. C., Wevill, D., Carpenter, L., Rickard, A. R., and Monks, P. S.: Direct evidence for coastal iodine particles from Laminaria macroalgae - linkage to emissions of molecular iodine, Atmos. Chem. Phys., 4, 701-713, doi:10.5194/acp-4-701-2004, 2004.

McFiggans, G., Bale, C. S. E., Ball, S. M., Beames, J. M., Bloss, W. J., Carpenter, L. J., Dorsey, J., Dunk, R., Flynn, M. J., Furneaux, K. L., Gallagher, M. W., Heard, D. E., Hollingsworth, A. M., Hornsby, K., Ingham, T., Jones, C. E., Jones, R. L., Kramer, L. J., Langridge, J. M., Leblanc, C., LeCrane, J.-P., Lee, J. D., Leigh, R. J., Longley, I., Mahajan, A. S., Monks, P. S., Oetjen, H., Orr-Ewing, A. J., Plane, J. M. C., Potin, P., Shillings, A. J. L., Thomas, F., von Glasow, R., Wada, R., Whalley, L. K., and Whitehead, J. D.: Iodine-mediated coastal particle formation: an overview of the Reactive Halogens in the Marine Boundary Layer (RHaMBLe) Roscoff coastal study, Atmos. Chem. Phys., 10, 2975-2999, doi:10.5194/acp-10-2975-2010, 2010.

Monahan, E. C., Spiel, D. E., and Davidson, K. L.: A model of marine aerosol generation via whitecaps and wave disruption, in: Oceanic Whitecaps, edited by: Monahan, E. C. and Niocaill, G. M., 167-174, D. Reidel, Norwell, Mass., 1986.

Myrup, L. O. and Ranzieri, A. J.: A Consistent Scheme for Estimating Diffusivities to Be Used in Air Quality Models, Tech. Rep. CA-DOT-TL-7169-3-76-32, California Department of Transportation, 1976.

O’Dowd, C. D., Smith, M. H., Conserdine, I. E., and Lowe, J. A.: Marine aerosol, sea salt, and the marine sulphur cycle: a short review, Atmos. Environ., 31, 73-80, 1997.

O’Dowd, C. D., Jimenez, J. L., Bahreini, R., Flagan, R. C., Seinfeld, J. H., Hameri, K., Pirjola, L., Kulmala, M., and Jennings, S. G.: Marine aerosol formation from biogenic emissions, Nature, 417, 632-636, 2002.

Palmer, C. J., Anders, T. L., Carpenter, L. J., Küpper, F. C., and McFiggans, G.: Iodine and halocarbon response of Laminaria Digitata to oxidative stress and links to atmospheric new particle production, Environ. Chem., 2, 282-290, 2005.

Pechtl, S., Lovejoy, E. R., Burkholder, J. B., and von Glasow,
R.: Modeling the possible role of iodine oxides in atmospheric new particle formation, Atmos. Chem. Phys., 6, 505523, doi:10.5194/acp-6-505-2006, 2006.

Peters, C., Pechtl, S., Stutz, J., Hebestreit, K., Hönninger, G., Heumann, K. G., Schwarz, A., Winterlik, J., and Platt, U.: Reactive and organic halogen species in three different European coastal environments, Atmos. Chem. Phys., 5, 3357-3375, doi:10.5194/acp-5-3357-2005, 2005.

Platt, U. and Hönninger, G.: The role of halogen species in the troposphere, Chemosphere, 51, 325-338, 2003.

Porter, J. N. and Clarke, A. D.: Aerosol size distribution models based on in situ measurements, J. Geophys. Res., 102, 60356045, 1997.

Press, W. H., Flannery, B. P., Teukolsky, S. A., and Vetterling, W. T.: Numerical Recipes (FORTRAN Version), Cambridge University Press, Cambridge, 1989.

Pyles, R. D., Weare, B. C., Paw U, K. T., and Gustafson, W.: Coupling between the University of California, Davis, Advanced Canopy-Atmosphere-Soil Algorithm (ACASA) and MM5: preliminary results for July 1998 for Western North America, J. Appl. Meterol., 42, 557-569, 2003.

Pyles, R. D., Paw U, K. T., and Falk, M.: Directional wind shear within an old-growth temperate rainforest: observations and model results, Agr. Forest Meteorol., 125, 19-31, doi:10.1016/j.agrformet.2004.03.007, 2004.

Quinn, P. K., Bates, T. S., Johnson, J. E., Covert, D. S., and Charlson, R. J.: Interactions between the sulfur and reduced nitrogen cycles over the central Pacific Ocean, J. Geophys, Res., 95, 16405-16416, 1990.

Read, K. A., Mahajan, A. S., Carpenter, L. J., Evans, M. J., Faria, B. V. E., Heard, D. E., Hopkins, J. R., Lee, J. D., Moller, S. J., Lewis, A. C., Mendes, L., McQuaid, J. B., Oetjen, H., Saiz-Lopez, A., Pilling, M. J., and Plane, J. M. C.: Extensive halogen-mediated ozone destruction over the Tropical Atlantic Ocean, Nature, 453, 1232-1235, doi:10.1038/nature07035, 2008.

Saiz-Lopez, A. and Plane, J. M. C.: Novel iodine chemistry in the marine boundary layer, Geophys. Res. Lett., 31, L04112, doi:10.1029/2003GL019215, 2004.

Saiz-Lopez, A., Plane, J. M. C., and Shillito, J. A.: Bromine oxide in the mid-latitude marine boundary layer, Geophys. Res. Lett., 31, L03111, doi:10.1029/2003GL018956, 2004.

Saiz-Lopez, A., Plane, J. M. C., McFiggans, G., Williams, P. I., Ball, S. M., Bitter, M., Jones, R. L., Hongwei, C., and Hoffmann, T.: Modelling molecular iodine emissions in a coastal marine environment: the link to new particle formation, Atmos. Chem. Phys., 6, 883-895, doi:10.5194/acp-6-883-2006, 2006.

Saiz-Lopez, A., Plane, J. M. C., Mahajan, A. S., Anderson, P. S., Bauguitte, S. J.-B., Jones, A. E., Roscoe, H. K., Salmon, R. A., Bloss, W. J., Lee, J. D., and Heard, D. E.: On the vertical distribution of boundary layer halogens over coastal Antarctica: implications for $\mathrm{O}_{3}, \mathrm{HO}_{\mathrm{x}}, \mathrm{NO}_{\mathrm{x}}$ and the $\mathrm{Hg}$ lifetime, Atmos. Chem. Phys., 8, 887-900, doi:10.5194/acp-8-887-2008, 2008.

Sander, R. and Crutzen, P. J.: Model study indicating halogen activation and ozone destruction in polluted air masses transported to the sea, J. Geophys. Res., 101, 9121-9138, 1996.

Sander, R., Keene, W. C., Pszenny, A. A. P., Arimoto, R., Ayers, G. P., Baboukas, E., Cainey, J. M., Crutzen, P. J., Duce, R. A., Hönninger, G., Huebert, B. J., Maenhaut, W., Mihalopoulos, N., 
Turekian, V. C., and Van Dingenen, R.: Inorganic bromine in the marine boundary layer: a critical review, Atmos. Chem. Phys., 3, 1301-1336, doi:10.5194/acp-3-1301-2003, 2003.

Saunders, R. W. and Plane, J. M. C.: Formation Pathways and Composition of Iodine Oxide Ultra-Fine Particles, Environ. Chem., 2, 299-303, doi:10.1071/EN05079, 2005.

Saunders, R. W., Kumar, R., Gómez Martín, J. C., Mahajan, A. S., Murray, B. J., and Plane, J. M. C.: Studies of the formation and growth of aerosol from molecular iodine precursor, Z. Phys. Chem., 224, 1095-1117, doi:10.1524/zpch.2010.6143, 2010.

Slinn, S. A. and Slinn, W. G. N.: Predictions for particle deposition on natural waters, Atmos. Environ., 14, 1013-1016, 1980.

Topping, D., Lowe, D., and McFiggans, G.: Partial Derivative Fitted Taylor Expansion: An efficient method for calculating gas-liquid equilibria in atmospheric aerosol particles: 1. Inorganic compounds, J. Geophys. Res., 114, D04304, doi:10.1029/2008JD010099, 2009.

Toyota, K., Takahashi, M., and Akimoto, H.: Modeling multiphase halogen chemistry in the marine boundary layer with size-segregated aerosol module: implications for quasi-sizedependent approach, Geophys. Res. Lett., 28, 2899-2902, doi:10.1029/2001GL012916, 2001.
Vogt, R., Crutzen, P. J., and Sander, R.: A mechanism for halogen release from sea-salt aerosol in the remote marine boundary layer, Nature, 383, 327-330, 1996.

Vogt, R., Sander, R., von Glasow, R., and Crutzen, P. J.: Iodine Chemistry and its Role in Halogen Activation and Ozone Loss in the Marine Boundary Layer: A Model Study, J. Atmos. Chem., 32, 375-395, 1999.

von Glasow, R., Sander, R., Bott, A., and Crutzen, P. J.: Modeling halogen chemistry in the marine boundary layer 1 . Cloud-free MBL, J. Geophys. Res., 107, 4341, doi:10.1029/2001JD000942, 2002.

Wada, R., Beames, J. M., and Orr-Ewing, A. J.: Measurement of IO radical concentrations in the marine boundary layer using a cavity ring-down spectrometer, J. Atmos. Chem., 58, 69-87, doi:10.1007/s10874-007-9080-z, 2007.

Whalley, L. K., Furneaux, K. L., Gravestock, T., Atkinson, H. M., Bale, C. S. E., Ingham, T., Bloss, W. J., and Heard, D. E.: Detection of iodine monoxide radicals in the marine boundary layer using laser induced fluorescence spectroscopy, J. Atmos. Chem., 58, 19-39, 2007. 